\title{
Knjiga Lucija Cecilija izpovedovalcu Donatu o smrtih preganjalcev
}

\section{Prevedel Milan Lovenjak}

[1] (1) Gospod je uslišal tvoje molitve, najdražji Donat, ki si jih vsako uro, vsak dan, izlival pred njegovim obličjem, kot tudi molitve drugih naših bratov, ki so s slavnim pričevanjem za zasluge za vero prejeli večno krono. (2) In glej, po uničenju vseh sovražnikov, ko je po svetu ponovno vzpostavljen mir, se pred kratkim porušena Cerkev ponovno dviga in se po Gospodovi milosti v še večji slavi gradi tempelj Boga, ki so ga podrli brezbožni. (3) Bog je namreč vzpodbudil vladarje, ${ }^{1}$ ki so odpravili zločinske in krute ukaze tiranov in poskrbeli za dobro človeškega rodu, tako da je - kot da bi bili pregnani oblaki najbolj žalostnih časov - duše vseh razveselil prijeten in trajen mir. (4) Sedaj, po divjih viharjih črne nevihte, je zrak spet prijeten in ponovno sije željena luč. Bog je sedaj uslišal tudi molitve svojih služabnikov, z nebeško pomočjo dvignil zavržene in ponižane in $\mathrm{z}$ uničenjem zarote nevernikov obrisal solze žalujočih. (5) Tisti, ki so zasmehovali Boga, so na tleh, tisti, ki so podrli sveti tempelj, so padli še nižje, tisti, ki so mesarili pravične, so pogubili svoje škodljive duše $\mathrm{z}$ nebeško kugo in z zasluženim trpljenjem. (6) To se je zgodilo pozno, vendar z vso ostrino in kot je primerno. (7) Bog je namreč le odložil njihove kazni, da bi potem preko njih dal veličastne in čudežne zglede, iz katerih bi poznejši rodovi spoznali, da je Bog samo eden in da je on sodnik, ki določa primerne kazni nevernikom in preganjalcem. (8) Sklenil sem pisati o njihovih smrtih, da bodo vsi tisti, ki temu niso bili priča, in tisti, ki bodo živeli pozneje, vedeli, kolikšno moč in veličino je pokazal najvišji Bog, da bi izbrisal in uničil sovražnike svojega imena. Primerno je torej, da od samega začetka, od takrat, ko je bila ustanovljena Cerkev,

1 Konstantina in Licinija, ki sta $\mathrm{z}$ milanskim ediktom krščanstvo izenačila $\mathrm{z}$ drugimi religijami (prim. pogl. 48). 
predstavim, kdo so bili njeni preganjalci in s kakšnimi kaznimi jih je kaznovala strogost nebeškega sodnika.

[2] (1) Kot beremo zapisano, so Judje proti koncu vladavine cesarja Tiberija ${ }^{2}$ križali našega Gospoda Jezusa Kristusa na deseti dan pred aprilskimi kalendami ${ }^{3} \mathrm{v}$ letu, ko sta bila konzula dva Gemina. ${ }^{4}$ (2) Ko je tretji dan vstal, je zbral učence, ki jih je strah zaradi njegovega prijetja pognal v beg, ostal z njimi štirideset dni, odprl njihova srca in jim razlagal spise, ki so jim bili do takrat nerazumljivi in zapleteni. Naročil jim je in jih podučil, kako naj oznanjajo njegov nauk in resnico, in jim razložil sveto učenost Nove zaveze. (3) Ko je izpolnil to nalogo, ga je ovil nevihtni oblak in ga skritega pred človeškimi očmi dvignil v nebo. (4) Učenci - takrat jih je bilo enajst - ki so namesto izdajalca Juda medse sprejeli Matija, so se kmalu zatem ${ }^{5}$ razpršili po vsem svetu, da bi pridigali o evangeliju, kot jim je zapovedal njihov učitelj - Gospod. Tako so petindvajset let, vse do začetka dobe cesarja Nerona, po vseh provincah in mestih postavljali temelje Cerkve. (5) Ko je že vladal Neron, ${ }^{6}$ je Peter prišel v Rim in naredil nekaj čudežev $\mathrm{z}$ močjo tega istega Boga, ki mu je dal to moč, številne je spreobrnil $\mathrm{k}$ pravičnosti in postavil zvest in trden tempelj Bogu. (6) Ko je bilo to sporočeno Neronu in ko je izvedel, da vsak dan, ne samo v Rimu ampak vsepovsod, velika množica ljudi opušča čaščenje malikov in z obsojanjem stare vere prehaja $\mathrm{k}$ novi, ${ }^{7}$ se je - strašen in neusmiljen tiran, kot je bil - lotil rušenja nebeškega templja in uničevanja pravičnosti ter je kot prvi med vsemi preganjal božje služabnike, ${ }^{8}$ dal je križati Petra in ubiti Pavla. (7) Vendar to ni ostalo nekaznovano. Bog je namreč videl tlačenje svojega ljudstva. Vržen $s$ cesarskega dostojanstva in odstranjen z najvišjega položaja je tiran nenadoma nemočen izginil, lius Geminus) in Gaj Fufij Gemin (C. Fufius Geminus). Po drugem izročilu je bil datum Kristusove smrti 25. marec 33. Kristusovo smrt omenja tudi Tacit ob opisu Neronovih preganjanj kristjanov po velikem požaru v Rimu leta 64 (Annales 15.44.3).

5 Mathia \& Paulo v rokopisu je napaka prepisovalca za Mathia post paulo, verjetno $\mathrm{z}$ okrajšavo post na eno črko, $\mathrm{p}^{\mathrm{a}}$ ali $\mathrm{p}^{\mathrm{t}}$ (gl. Gordon, De mortibus, 30-31).

6 Neron je vladal od 13. oktobra 54 do 8. junija 68.

7 Podobno navaja Dioklecijanov odlok proti manihejcem, izdan 31. marca 302, da se zaradi nove religije ne sme zanemarjati stare (podrobneje o tem Roberto, Diocleziano, 189-194).

8 Tacit poroča, da je Neron kristjane obtožil velikega požara v Rimu in sovraštva do človeškega rodu, kar je bil vzrok silovitih preganjanj (Anali 15.44.3-5). 
tako da pri tej zlobni zveri ni znan niti kraj pokopa. ${ }^{9}$ (8) Zato nekateri nespametneži verjamejo, da je bil zgolj nekam prestavljen, da je ostal živ in da se bo po Sibilini prerokbi »pobegli morilec matere vrnil s konca sveta «, tako da bo prvi preganjalec kristjanov tudi zadnji in bo predhodnik Antikristovega prihoda, (9) čemur pa ne gre verjeti. Nekateri naši sveti razglašajo, da bo tako, kot sta bila dva preroka ${ }^{10}$ živa prenešena in se bosta vrnila ob koncu časov pred sveto in večno oblastjo Kristusa, ki se je začela spuščati - na enak način menijo, da bo prišel tudi Neron kot predhodnik in glasnik hudiča, preden bo ta prišel opustošit zemljo in uničit človeški rod.

[3] (1) Nekaj let zatem je nastopil drugi, nič manjši tiran [Domicijan]. Ko je izvajal nezaslišano tiranijo, bi lahko še dolgo varno sedel na vratu svojim podložnikom in vladal, če ne bi iztegnil nečistih rok proti Gospodu. ${ }^{11}$ (2) Ko je bil na pobudo demonov napeljan k preganjanju pravičnega ljudstva, je padel v roke sovražnikov in plačal kazen. Pri tem maščevanju ni bilo dovolj, da je bil ubit v svoji palači, pač pa je bil izbrisan tudi spomin na njegovo ime..$^{12}$ (3) Potem ko je postavil številne čudovite stavbe, ko je zgradil Kapitol in druge veličastne spomenike, je senat tako preganjal njegovo ime, da niti na napisih ni ostala nobena sled in da je bil mrtev z najstrožjimi ukrepi obsojen na večno sramoto. (4) Tiranove odredbe so bile razveljavljene, tako da Cerkev ni bila le obnovljena v svoje nekdanje stanje, ampak je zablestela še bolj sijajno in še bolj cvetoče. V naslednjem obdobju, ko so številni dobri rimski vladarji prevzeli krmilo in vodenje cesarstva, Cerkev ni utrpela nobenega napada sovražnikov in je razširila svoje roke proti vzhodu in zahodu. ${ }^{13}(5)$ Noben kraj na zemlji ni bil tako odročen, da tja ne bi

9 Po Neronovi smrti so se razširile govorice, da je le pobegnil čez Evfrat, od koder bo ponovno pridobil oblast, a Svetonij poroča, da sta ga pokopali njegovi dojilji Egloga in Aleksandrija v družinski grobnici Domicijev (Svetonij, Neron 50).

10 Navezava na obe priči oziroma preroka iz Janezove Apokalipse (Razodetje 11,314), ki tam sicer nista imenovana, a ju v eksegezi ponavadi identificirajo z Elijo in Henohom (Städele, Laktanz, 97, op. 9).

11 Domicijan je vladal od 14. septembra 81 do 18 . septembra 96. O njegovem preganjanju piše tudi Evzebij, Hist. eccl. 3.17-20. V krščanskem izročilu nastopa kot drugi preganjalec kristjanov, ki pa ni tako strašen kot Neron (gl. Bratož, Rimska zgodovina, 255-256 in 426).

12 Doletela ga je kazen $s$ "prekletstvom spomina« (damnatio memoriae), iz vseh javnih dokumentov in $\mathrm{z}$ vseh spomenikov so izbrisali njegovo ime.

13 Izpuščeni so cesarji, ki so prav tako veljali za preganjalce, Trajan, Mark Avrelij, Septimij Sever in Maksimin Tračan. Posebej pomembni pričevanji iz Trajanove dobe sta pismo Plinija Mlajšega, namestnika v provinci Pont in Bitinija med 111 in $113, \mathrm{v}$ katerem cesarja sprašuje, kako naj ravna s kristjani, in kratek cesarjev 
prodrla vera, nobeno ljudstvo ni živelo po tako divjih običajih, da ne bi sprejelo resničnega čaščenja Boga in se spreobrnilo k pravičnosti. Toda potem je bil dolgi mir ponovno prekinjen.

[4] (1) Po mnogih letih se je namreč pojavila prekleta zver Decij, ${ }^{14}$ ki je preganjal Cerkev; kdo bi namreč preganjal pravičnost, če ne zločinec? (2) In kot da bi le za to dosegel najvišje časti, je začel divjati proti Bogu in kmalu padel. (3) Odpravil se je namreč proti Karpom, ki so takrat zasedali Dacijo in Mezijo, takoj so ga obkolili barbari in uničili skupaj z velikim delom vojske. ${ }^{15}$ Tako ga ni doletela niti čast pokopa, temveč je slečen in gol, kot je to primerno za sovražnika Boga, obležal kot hrana zverem in pticam.

[5] (1) Ne dolgo zatem je Valerijan, ${ }^{16}$ ki ga je zgrabilo podobno besnenje, dvignil umazane roke proti Bogu in kljub kratki vladavini prelil veliko pravične krvi. Bog ga je kaznoval s povsem novo in nenavadno kaznijo, da bi poznejšim rodovom služil kot zgled, kako bodo sovražniki Boga za svoje zločine vedno prejeli zasluženo plačilo. (2) Ko so ga ujeli Perzijci, ni izgubil samo cesarske oblasti, ki jo je sramotno zlorabljal, ampak tudi svobodo, ki jo je odvzel drugim in je potem živel v najsramotnejšem ujetništvu. (3) Kralj Perzijcev Šapur, ${ }^{17}$ tisti, ki ga je ujel, je namreč takrat, ko se je hotel povzpeti na voz ali konja,

odgovor (Plinij, Pisma 10, 96 in 97; prevod v: Fran Ksaver Lukman, Kristusovi pričevalci, Celje 1983, 21-22; gl. o tem podrobneje Bratož, Rimska zgodovina 426-428).

14 Vladal je od septembra/oktobra 249 do junija 251. O Decijevem preganjanju pišeta tudi Ciprijan, De lapsis in Epistulae, in Evzebij, Hist. ecc. 6.40.4. Preganjanje je sprožil Decijev odlok o obveznem žrtvovanju bogovom (supplicatio) za vse prebivalce, verjetno izdan leta 249 (podrobneje o tem Hekster, Rome and Its Empire, 70-77).

15 Decij je kot prvi rimski cesar padel na bojnem polju v bitki z Goti pri Abritu (Abrittus), ok. $70 \mathrm{~km}$ severozahodno od Marcianopole v severni Bolgariji. V bitki na močvirnem terenu je umrl tudi njegov sin Herenij Etrusk, vojska pa je bila skoraj v celoti uničena.

16 Valerijan je vladal od 253 do 260 , ko je padel v perzijsko ujetništvo, umrl je po letu 262. Izdal je dva edikta proti kristjanom, prvega 257, drugega 258. Njegova preganjanja, ki jih omenjata Evzebij (Hist. eccl. 7.10-12) in Ciprijan (Epistulae, 76-80), je ustavil njegov sin Galijen (Evzebij, Hist. eccl. 7.13); gl. Glas, Valerian: Kaisertum und Reformansätze, 275-305).

17 Vladal je med letoma 241 in 272 . Med letoma 244 in 260 je premagal tri rimske cesarje, Gordijana III., Filipa Arabca in Valerijana. Na skalnem reliefu v Naqšsi-Rustemu pri Perzepolisu je upodobljen perzijski kralj na konju, pred njim pa oseba v rimski opravi, ki kleči, verjetno cesar Valerijan. Da je Šapur I. lastnoročno zajel cesarja Valerijana, poroča trojezični napis Res gestae divi Saporis (gl. Bratož, Rimska zgodovina, 325, z delnim prevodom). 
ukazal Rimljanu, naj se skloni, in mu stopil na hrbet, ga zasmehoval in govoril, da je prava resnica to, ne pa tisto, kar Rimljani slikajo na zidovih in ploščah. (4) Tako je on, ki je bil po pravici premagan, živel še toliko, da je bilo rimsko ime še dolgo v posmeh barbarom. (5) K njegovi kazni je bilo dodano tudi to, da je imel sicer sina cesarja, ${ }^{18}$ vendar v njem ni našel maščevalca svojega ujetništva in najhujšega suženjstva, niti ga ta ni poskušal odkupiti. (6) Ko je pozneje končal nečastno življenje v tej sramoti, so mu odrli kožo z mesa, jo obarvali $\mathrm{z}$ rdečo barvo in shranili v templju barbarskih bogov kot spomin na najslavnejše zmage, da bi jo lahko vedno kazali našim poslancem, češ da se Rimljani ne smejo preveč zanašati na svojo moč, ko poleg perzijskega kralja vidijo ostanke ujetega rimskega vladarja. (7) Bog je zadal takšne kazni svojim skrunilcem; ali ni čudno, da se je sploh še kdo drznil, ne storiti, ampak sploh pomisliti na kakšno dejanje proti veličini edinega Boga, stvarnika in vladarja nad vsem?

[6] (1) Avrelijan, ki je bil divje in nagle narave, je, čeprav se je spominjal Valerijanovega ujetništva, pozabil na njegov zločin in kazen in je s svojimi okrutnimi dejanji izzval božjo jezo. ${ }^{19} \mathrm{Ni}$ mu bilo dovoljeno, da bi izpeljal, kar je nameraval, ampak je bil zaustavljen že takoj na začetku svojega besnenja. (2) Njegovi kruti razglasi še niso prispeli do oddaljenih provinc, ko je v Kenofruriju, kraju v Trakiji, v krvi ležal na tleh, potem ko so ga zaradi lažne obsodbe ubili njegovi prijatelji. ${ }^{20}$ (3) Zaradi takih in tako številnih zgledov bi se morali poznejši tirani krotiti - vendar se niso ustrašili, temveč so še drzneje nastopili proti Bogu.

[7] (1) Ko je Dioklecijan, ${ }^{21}$ ki je bil izumitelj novih zločinov in spodbujevalec zlih dejanj, vse že popolnoma uničil, ni mogel zadržati rok niti pred Bogom. (2) Zaradi pohlepa in strahopetnosti je preobrnil ves svet. Še tri druge je pritegnil v svojo vladavino, tako da je bil svet razdeljen na štiri dele, vojska pa večkrat povečana; vsak je hotel imeti veliko večje število vojakov kot prejšnji vladarji, ki so sami vladali celotni državi. ${ }^{22}$ (3) Število tistih, ki so prejemali, je začelo postajati toliko večje od števila tistih, ki so morali dajati, da je prekomernost dajatev izčrpala moč zemljiških najemnikov, polja so se opuščala, obdelana zemljišča pa

Valerijanov sin in naslednik Galijen je vladal od septembra/oktobra 253 dalje kot očetov sovladar in do približno septembra 268. Prekinil je z očetovo versko politiko in z ediktom odredil konec preganjanja kristjanov. Vladal je med septembrom 270 in septembrom/oktobrom 275. Avrelijan je umrl kot žrtev oficirske zarote v Trakiji. Za uvod v Dioklecijanovo dobo gl. Demandt, Spätantike, 57-75, in Bratož, Med Italijo in Ilirikom, 58-6o; novejše monografije so objavili Roberto, Diocleziano (2014), Rémy, Dioclétien (2016), in Carlà-Uhink, Diocletiano (2019). 
spreminjala v gozdove. (4) In da bi se vse napolnilo s strahom, so bile province razdeljene na koščke, ${ }^{23}$ številni upravitelji, množica uradov, mnogi finančniki, nadzorniki in namestniki prefektov so nadzorovali posamezne predele in že skoraj vsako mesto; le redko so se ukvarjali s civilnimi zadevami, pogosto pa z obtožbami in zaplembami. Neskončni odvzemi stvari brez števila niso bili samo pogosti, temveč stalni, pri tem so se dogajale neznosne krivice. (5) Kako bi se lahko sploh prenašalo to, kar je bilo potrebno za vzdrževanje vojske? Zaradi velikega pohlepa ni dovolil, da bi se zmanjšala njegova zakladnica, temveč je stalno in s posebnimi zahtevami povečeval bogastvo, namenjeno za izdatke, da bi to, kar je nagrabil, ostalo celo in nedotaknjeno. (6) Ker je z različnimi nepravičnimi dejanji povzročil veliko draginjo, je z zakonom skušal določiti cene stvarem, namenjenim prodaji. ${ }^{24}$ (7) Zaradi majhnih in neznatnih stvari je bilo takrat prelite veliko krvi, blago zaradi strahu ni prišlo v prodajo in nastopila je še večja draginja, vse dokler ni bil po smrti številnih zakon razveljavljen. (8) Temu se je pridružila še nekakšna neskončna strast po gradnjah, ${ }^{25} \mathrm{v}$ provincah pa nič manjša izterjava delavcev, obrtnikov, tovornih vozov in vsega, kar je potrebno za izvajanje gradbenih del. (9) Tu so se gradile bazilike, tam dirkališče, tukaj kovnica denarja, tam delavnica orožja, tukaj hiša za ženo, tam za hčer. Povsem iznenada je bil porušen večji del mesta. Vsi so se

23 Število provinc se je povečalo z 48 pred Dioklecijanom na $95 \mathrm{v}$ času ok. 314, ko je nastal Laterculus Veronensis, seznam diecez s pripadajočimi provincami (Eck, Neuorganisation der Provinzen, 133-140). Kasneje v pozni antiki se je število provinc povečalo na 120. Dioklecijan si je očitno prizadeval za izboljšano administrativno in davčno politiko $\mathrm{z}$ razdeljeno in gosto prepleteno ter birokratsko hierarhijo. Med provincami in prefekturami Laterculus Veronensis kot nove enote omenja dieceze, ki so jih upravljali vikarji (vicarius) kot namestniki pretorijanskega prefekta (praefectus praetorio). Najmanjše upravne enote so bila še naprej mesta (civitates) z lastno samoupravo (gl. Demandt, Die Spätantike, $67)$.

24 Besedilo edikta, na podlagi katerega je Dioklecijan zamejil cene živil, blaga in storitev, je deloma znano na podlagi čez sto tridesetih fragmentov napisnih kopij iz Grčije in vzhodnih provinc. Izdan je bil med 1. novembrom in 31. decembrom $301 \mathrm{v}$ imenu vseh štirih tetrarhov (praef. 1-4), vsebinsko se navezuje na denarno reformo, ki je stopila v veljavo 1. septembra 301. Temeljni objavi z rekonstrukcijo latinskega in grškega besedila: Lauffer, Diokletians Presiedikt, in Giacchero, Edictum Diocletiani. Mort. pers je eden redkih pisnih virov, ki edikt omenjajo (gl. Lauffer, Diokletians Preisedikt, 58-59). Za Dioklecijanove zakone gl. Dillon, The Emperor's New Prose, 285-343 (za edikt 320-338).

25 O Dioklecijanovi infinita cupiditas aedificandi prim. Roberto, Diocleziano, 143-144. Dejansko so imele od tega korist tudi province, saj so bile obnovljene ali zgrajene tudi številne ceste in drugi infrastrukturni objekti. 
izseljevali z ženami in otroci, kot da so mesto osvojili sovražniki. (10) In ko so bila ta dela ob pogubi provinc končana, je rekel: »Ni zgrajeno prav. Potrebno je narediti drugače.« Tako je bilo nujno ponovno rušiti in spreminjati, da bi potem lahko spet rušili. Pri tem ga je vedno vodila nora želja, da bi Nikomedijo izenačil z Rimom. (11) Tega niti omenjal ne bom, kako številni so umrli zaradi bogastva in lastnine. To je namreč postalo povsem običajno in zaradi navajenosti na slabo že skoraj dopustno. (12) Njegova posebnost pa je bila naslednje. Kjerkoli je videl kakšno dobro obdelano zemljišče ali sijajnejšo stavbo, je takoj pripravil obtožbo in smrtno obsodbo za lastnika, kot da tujega ne bi mogel odvzeti brez prelivanja krvi.

[8] (1) Kaj pa njegov brat Maksimijan, imenovan Herkulij? ${ }^{26}$ Zelo mu je bil podoben; ne bi namreč mogla biti povezana v tako zvestem prijateljstvu, če ne bi bili pri obeh prisotni isti duh, enak naklep, ista volja in enotno mnenje. (2) Samo v tem sta se razlikovala, da je bil pri prvem [Dioklecijanu] večji pohlep, vendar tudi več strahopetnosti, pri drugem pa je bil pohlep manjši, imel pa je več moči - a ne da bi delal dobro, ampak da bi delal slabo. (3) Ko je imel v oblasti Italijo in so se mu podvrgle najbogatejše province kot Afrika ali Hispanija, ni bil tako prizadeven, da bi varoval bogastvo, ki mu je v obilju pritekalo iz njih. (4) Ko je bilo potrebno, ni manjkalo zelo bogatih senatorjev, pod lažnimi obtožbami obtoženih poseganja po oblasti, tako da je bil senat stalno brez najboljših članov. V okrutno cesarsko blagajno se je stekalo nepravično pridobljeno bogastvo. (5) Razuzdanost tega kužnega človeka ni služila samo za kvarjenje mož, kar je že samo po sebi odvratno in vredno prezira, ampak tudi za skrunitev hčerk odličnikov. Kamorkoli se je namreč odpravil, je tam iz objema staršev takoj trgal device. (6) V teh stvareh je užival, kajti menil je, da je sreča njegove vladavine $\mathrm{v}$ tem, da ničesar ne odtegne svoji zli strasti in poželenju. (7) Konstancija ne omenjam, kajti bil je povsem drugačen od ostalih in vreden, da bi sam vladal svetu. ${ }^{27}$

[9] (1) Drugi Maksimijan [Galerij], ${ }^{28} \mathrm{ki}$ ga je Dioklecijan sprejel za zeta, ni bil le slabši od teh dveh, ki ju je občutil naš čas, temveč najslabši

26 Maksimijan se je rodil okrog 250 v bližini Sirmija. Leta 285 je postal cezar, 286 pa avgust za zahodni del cesarstva (Italijo, Galijo, Britanijo in Afriko), njegova prestolnica je bila Mediolan (Milano). Od takrat naprej se je imenoval Mark Avrelij Valerij Maksimijan.

27 Konstancija avtor zaobide, čeprav je bil udeležen pri ukrepih tetrarhov (prim. tudi 15.7 in 18.11). Po imenovanju za cezarja je bilo njegovo ime Flavij Valerij Konstancij Herkulij.

28 Galerij je postal cezar na Vzhodu leta 293, ko se je poročil z Dioklecijanovo hčerko Valerijo. Od takrat naprej se je imenoval Gaj Galerij Valerij Maksimijan, 
od vseh slabih, ki so kadarkoli živeli. (2) V tej zveri je bilo barbarstvo po naravi in zverinskost, tuja rimski krvi: to ni čudno, saj je njegova mati izvirala iz območja onstran Donave in se je zaradi napadov Karpov, potem ko je prišla čez reko, zatekla v Dacijo. (3) Tudi njegovo telo je bilo skladno z njegovo nravjo, veliko po rasti, z veliko mesa, ki je naraslo in se napihnilo do grozljive velikosti. (4) Tako je z besedami, dejanji in videzom pri vseh vzbujal grozo in strah. Tudi njegov tast se ga je zelo bal, vzrok tega strahu pa je bilo naslednje. (5) Perzijski kralj Narzes ${ }^{29}$ je spodbujen z zgledom svojega starega očeta Šapurja poskušal z veliko vojsko zavzeti Vzhod. (6) Takrat se mu Dioklecijan, ki je bil ob vseh nemirih plašen in malodušen, ravno tako pa se je bal tudi Valerijanovega zgleda, ni upal iti nasproti, pač pa je tega [Galerija] poslal v Armenijo, sam pa je ostal na Vzhodu in čakal na razplet. (7) Ta [Galerij] pa je s pripravljeno zasedo brez težav premagal barbare, ki imajo navado, da se podajo na vojno z vsemi svojimi rečmi; ovirala sta jih njihova številčnost in ukvarjanje s svojo opremo. Potem ko je pognal kralja Narzesa v beg, se je vrnil z velikim plenom in dobrinami, kar ga je navdalo z ošabnostjo, Dioklecijana pa s strahom. (8) Po tej zmagi je postal tako prevzeten, da ni bil več zadovoljen z nazivom cezarja. Ko je slišal, da ga kdo tako naslavlja v pismih, ki so mu bila poslana, je z grozljivim glasom kričal:»Kako dolgo še cezar?« (9) Potem se je obnašal skrajno prevzetno. Želel je, da bi veljal in bil imenovan za Marsovega sina, kot da je drugi Romul, in je svojo mater Romulo obtožil prešuštva, da bi se zdelo, kako sam izvira od boga Marsa. ${ }^{30}$ (10) Vendar ne bom več govoril o njegovih dejanjih, da ne pomešam zaporedja dogodkov. Kajti šele takrat, ko je po odstavitvi tasta prejel cesarski naziv, je začel scela blazneti in prezirati vse. (11) Diokles - tako se je namreč imenoval, preden je postal cesar - bi, potem ko je uničil državo s takimi naklepi in ob takih kolegih, čeprav si zaradi svojih zločinov ne bi zaslužil nič dobrega, vendarle lahko še dolgo srečno vladal, če ne bi svojih rok umazal s krvjo pravičnih. (12) Sedaj bom opisal, kaj je bil vzrok preganjanja.

a ga pisec Mort. pers. vedno imenuje (drugi) Maksimijan. Sodba o njem je še posebej negativna, namenjeno mu je tudi največ prostora, češ da je glavni krivec za preganjanja. A viri ponujajo precej drugačno sliko o njem in o Dioklecijanovem odnosu in pričakovanjih od njega (gl. Leadbetter, Galerius, 114-155; za Galerija kot zakonodajalca gl. Brandt, Galerio legislatore, 17-24).

Narzes je vladal od 293-302. Leta 296 je vdrl v Armenijo in naslednje leto premagal Galerija, leta 298 pa ga je Galerij porazil (za Galerijevo perzijsko vojno gl. Leadbetter, Galerius, 88-100).

30 Dvojčka Romul in Rem sta bila sinova Marsa in vestalke Reje Silvije. 
[10] (1) Ko je deloval na Vzhodu - zaradi strahu je preiskoval, kaj se bo zgodilo v prihodnosti - je žrtvoval drobnico, da bi iz jeter izvedel, kaj se bo zgodilo. (2) Takrat so si njegovi služabniki, ki so poznali gospodarja in so mu pomagali pri žrtvovanju, čelo zaznamovali z znamenjem nesmrtnosti; to je pregnalo demone in zmotilo žrtvovanje. Haruspeksi so bili vznemirjeni, ker v drobovini niso našli običajnih znamenj, in so žrtvovanje ponavljali, kot da ga sploh ne bi izvedli. (3) Vendar zaklane žrtve niso pokazale ničesar, dokler ni predstojnik haruspeksov Tagis, ki je morda kaj posumil ali kaj videl, zatrdil, da žrtvovanje zato ni pokazalo ničesar, ker so bili pri božjih rečeh prisotni brezbožniki. (4) Takrat je on [Dioklecijan] besneč od jeze ukazal, da morajo žrtvovati ne samo tisti, ki so sodelovali pri žrtvovanjih, temveč vsi v palači, tistim, ki bi to zavrnili, pa zagroziti s šibanjem. V pismih, ki jih je poslal načelnikom vojaških enot, je ukazal, da morajo k brezbožnim žrtvovanjem prisiliti tudi vojake, če pa bi kdo to zavrnil, naj bo odpuščen iz vojaške službe. (5) Tako daleč sta šla njegova jeza in bes, vendar ni proti božji postavi ali veri ukrenil ničesar. (6) Ko je preteklo nekaj časa, je prispel v Bitinijo, da bi tam prezimil. Takrat je tja prispel tudi cezar Maksimijan [Galerij], podžgan v zločinski želji, da bi k preganjanju kristjanov spodbudil muhastega starca, ki je s tem že tudi začel. Kot sem izvedel, je bil vzrok njegovega besnenja naslednji.

[11] (1) Njegova mati, ki je bila zelo praznoverna ženska, je častila bogove gora, ${ }^{31}$ skoraj vsak dan je prirejala žrtvovanja in na obredne gostije vabila svoje sovaščane. Kristjani se jih niso udeleževali in so, medtem ko se je ona gostila s sovaščani, vztrajali v postu in molitvi. (2) Tako jih je začela sovražiti in je svojega sina, ki ni bil nič manj praznoveren, z ženskimi obtožbami nagovarjala k odstranjevanju teh ljudi. (3) Skozi vso zimo sta se [Dioklecijan in Galerij] posvetovala, pri tem ni smel biti navzoč nihče drug, vsi so bili prepričani, da razpravljata le o najvažnejših državnih zadevah. Starec se je dolgo upiral njegovi norosti in opozarjal, da bi bilo zelo nevarno vznemiriti cel svet in prelivati kri številnih, saj so ti vajeni rade volje umirati, dovolj bi bilo že, če bo ta vera prepovedana ljudem v palači ${ }^{32}$ in vojakom. (4) Vendar ni mogel ublažiti norosti nadutega človeka [Galerija]. Zato je sklenil poiskati mnenje prijateljev. ${ }^{33}$ (5) Njegova narava je bila namreč pokvarjena. Ko

$\mathrm{Ni}$ čisto jasno, katere poganske bogove je častila Galerijeva mati, morda Silvana. Za cesarske uradnike v palači gl. Porena, L'amministrazione palatina, 63-110. Že v dobi principata je imel cesar svet visokih uradnikov in zaupnikov, consilium principis, ki se je v Dioklecijanovih upravnih reformah preoblikoval v sacrum consistorium. Njegovi člani so se imenovali comites intra consistorium ali comites consistoriani (gl. Demandt, Spätantike, 276-277). Na omenjem sestanku v 
je sklenil narediti kaj dobrega, je to storil brez posvetovanja, da bi bil pohvaljen samo on; ko pa kaj slabega, je vedel, da bo to grajano, in je na posvet poklical številne, da bi lahko pripisal krivdi drugih tisto, kar je zagrešil sam. (6) Tako so poklicali maloštevilne uradnike in maloštevilne pripadnike vojske, da bi se jih izprašalo po vrstnem redu njihovega položaja. Nekateri so zaradi lastnega sovraštva govorili proti kristjanom, da bi jih bilo kot sovražnike boga in državne vere treba odstraniti, drugi, ki so čutili drugače in so spoznali prepričanje tega človeka, pa so se temu mnenju priključili zaradi strahu ali da bi ugajali. (7) Toda tudi takrat se cesar [Dioklecijan] ni uklonil in ni dal soglasja, temveč se je odločil vprašati bogove in je poslal haruspeksa k miletskemu Apolonu. Ta je odgovoril kot sovražnik božje vere. (8) Tako je bil odvrnjen od svoje namere in ker ni mogel nasprotovati prijateljem, cezarju ali Apolonu, je samo še poskušal ohraniti zmernost, da bi lahko to odločitev izpeljal brez prelivanja krvi - medtem ko je cezar hotel zažgati žive vse tiste, ki so odklonili žrtvovanje.

[12] (1) Za izvršitev teh stvari so iskali primeren in srečen dan, izbrane so bile terminalije, ${ }^{34}$ ki so sedem dni pred marčevskimi kalendami [23. februarja], da bi tej veri končno postavili neke vrste mejo. To je bil dan, ki prinesel je smrt in vzrok za strahoto, ${ }^{35}$ ki je doletela njih [cesarje] in ves svet. (2) Ko je napočil ta dan, oba starca [Dioklecijan in Maksimijan] sta takrat opravljala konzulat, eden osmega, drugi sedmega, je ob zori prefekt s poveljniki, tribuni in načelniki zakladnice prispel do cerkve. Razbili so vrata, iskali božji kip in zažigali spise, ki so jih našli. Dovoljeno je bilo plenjenje, dogajale so se ugrabitve, zastraševanja, vsesplošen beg. (3) Onadva sta vse to opazovala, cerkev, ki je stala na hribu, je bila namreč iz palače dobro vidna, in se prerekala, ali ne bi bilo morda bolje podtakniti požara. (4) Prevladalo je mnenje Dioklecijana, ki se je bal, da bi v velikem požaru zagorel tudi ostali del mesta. Cerkev so namreč obdajale številne in velike zgradbe. (5) Prišli so torej pretorijanci v urejenem sestavu, s sekirami in drugim orodjem so pritisnili $\mathrm{z}$ vseh strani in to čudovito svetišče v nekaj urah zravnali z zemljo.

[13] (1) Naslednji dan je bil objavljen edikt, ${ }^{36} \mathrm{v}$ katerem je bilo določeno, naj se pripadnikom te vere odvzamejo vse časti in vse dos-

Nikomediji sta sodelovala tudi praeses Bitinije Sosijan Hierokles in Porfirij (gl. Leadbetter, Galerius, 130-131).

34 Praznik boga meja Termina (Iuppiter Terminus; gl. Ovidij, Fasti 2.50; 2.639-684; Avguštin, De civitate Dei 7.7.

35 Vergilij, Eneida 4.169-170.

36 Ta edikt omenja tudi Evzebij, Hist. eccl. 2.4; 8.5.1. 
tojanstvo, naj bodo podvrženi mučenju, ne glede na to, iz katerega stanu izhajajo ali kateri položaj zasedajo, naj bo proti njim veljavna vsakršna obtožnica, sami pa ne smejo ukreniti ničesar zaradi krivic, zakonoloma in ropanja, ki bi jih doleteli; izgubili so tudi svobodo in pravico glasovanja. (2) Ta edikt je nekdo, čeprav to ni bilo prav, res pogumno odstranil in raztrgal ter pri tem porogljivo pripomnil, da so v njem objavljene zmage nad Goti in Sarmati. ${ }^{37}$ (3) Takoj so ga privedli [pred sodnike] in ne samo mučili, temveč so ga, kot je bilo določeno z zakonom, pekli na ognju, kar je s čudežno potrpežljivostjo zdržal, nato pa sežgali.

[14] (1) Toda cezar [Galerij] ni bil zadovoljen z določbami edikta; Dioklecijana je nameraval napasti na drug način. (2) Da bi ga spodbudil k odločitvi za najokrutnejša preganjanja, je namreč ukazal, naj tajni pomočniki zanetijo požar v palači, ${ }^{38}$ za kar so potem, ko je del palače že zgorel, obtožili kristjane in jih razglasili za državne sovražnike. Tako je poleg palače istočasno gorelo tudi samo ime kristjanov; češ da so se skupaj z evnuhi dogovorili o odstranitvi cesarjev, oba vladarja pa da bi bila skoraj živa sežgana v lastni palači. (3) Dioklecijan, ki je sicer vedno skušal dajati premeten in pameten vtis, ni ničesar posumil, temveč je podžgan zaradi jeze takoj ukazal mučiti vse svoje ljudi. (4) Sam je predsedoval procesom in izročal nedolžne mučenju z ognjem, na mučenje so obsojali tudi vsi sodniki in uradniki v palači. (5) Tekmovali so med sabo, kdo bo prvi kaj izvedel, vendar ni nihče odkril ničesar, saj ni nihče mučil cezarjevih [Galerijevih] služabnikov. Tudi sam [Galerij] je bil prisoten, pritiskal je in ni dopustil, da bi se besnenje nepremišljenega starca zmanjšalo. (6) Po preteku petnajstih dni je dal ponovno zanetiti požar; tega so sicer prej opazili, vendar njegovega povzročitelja ponovno niso odkrili. ${ }^{39}$ (7) Tedaj se je cezar sredi zime pripravil na pot, se odpravil še istega dne in razlagal, kako beži zato, da ne bi bil živ zažgan.

[15] (1) Cesar sedaj ni več toliko besnel proti domačim kot proti vsem; od vseh je k omadeževanju z žrtvovanjem najprej prisilil hčer Valerijo in ženo Prisko. (2) Nekoč najvplivnejši evnuhi, na katere se je prej opirala celotna palača in tudi on sam, so bili pobiti; duhovniki in njihovi pomočniki so bili zajeti in obtoženi brez kakršnegakoli dokaza ali priznanja, odvedeni skupaj z vsemi svojimi. (3) Ljudje obeh spolov edikt odstranil, Euthi(o)s (gl. Städele, Laktanz, 122, op. 38 ).

38 Požar omenjata tudi Evzebij, Hist. ecc. 8.6.6., in Konstantin v govoru Oratio ad sanctorum coetum, 25.

39 Tega drugega požara ne omenja noben drug vir. 
in vseh starosti so bili zajeti, da bi bili sežgani, vendar ne posamič, kajti bila jih je že velika množica, ampak so bili vsi hkrati obdani z ognjem. Služabnike so utopili v morju z mlinskim kamnom okrog vratu. (4) Nič manj nasilno ni bilo preganjanje ostalega ljudstva. Kajti sodniki so bili poslani v vsa svetišča in so vse ljudi silili k žrtvovanju. (5) Zapori so bili polni, iznašli so nezaslišane načine mučenja in da nikomur ne bi sodili na lahek način, so bili na sodiščih pred sodniškim tribunalom postavljeni žrtveniki, kjer bi obtoženi najprej lahko žrtvovali in tako predstavili svojo obrambo; do sodnikov so pristopali kot do bogov. (6) Do Maksimijana in Konstancija so prihajala pisma, naj ravnata enako, za njuno mnenje v tako važnih stvareh pa ni nihče niti vprašal. Stari Maksimijan se je temu glede Italije rad uklonil, saj ni bil preveč prizanesljiv. (7) Konstancij pa je zato, da se ne bi zdelo, kako ne posluša ukazov starejših, dopustil rušenje svetih shajališč, zidov, ki se jih da ponovno zgraditi, vendar pa je pravi božji tempelj, ki je v ljudeh, ohranil nedotaknjen.

[16] (1) Tako je bil tlačen ves svet in povsod, razen v Galiji, so od vzhoda do zahoda besnele tri najhujše zveri. (2) $D a$, če imel stotero bi ust in stotero jezikov, zraven pa glas iz železa, ne mogel bi vsega našteti, kar so ti zagrešili in kakšne jih čakajo kazni, ${ }^{\circ}{ }^{\circ}$ ki so jih sodniki izrekli pravičnim in nedolžnim v provincah. (3) Resnično, kaj je potrebno to pripovedovati, zlasti tebi, najdražji Donat, ki si bolj od ostalih izkusil nevihto besnečega preganjanja? (4) Kajti ko si dospel v roke prefekta Flakcina, nemajhnega morilca, nato pa Hierokla, bivšega namestnika in nato upravitelja, ki je bil začetnik in svetovalec pri izvedbi preganjanja, in potem v roke njegovega naslednika Priscilijana, ${ }^{41}$ si vsem pokazal zgled nepremagljivega poguma. (5) Devetkrat si bil podvržen mučenju in različnim mukam, devetkrat si premagal svoje nasprotnike s slavnim pričevanjem vere, devetkrat si v bitkah premagal hudiča in njegove pripadnike, $\mathrm{z}$ devetimi zmagami si slavil triumf nad tem svetom in njegovimi strahotami. (6) Kako prijeten je bil Bogu tisti prizor, ko te je videl kot zmagovalca, v katerega voz niso bili vpreženi beli konji ali divji sloni, pač pa sami triumfatorji! (7) To je resnični triumf, ko zagospodariš nad gospodarji. Premagani in ukročeni so bili namreč zaradi tvoje vrline, ko si z neomajno vero in močjo duha izničil njihove nečastne ukaze in preziral vse uredbe in strahote tiranske oblasti. (8) Proti tebi niso mogli nič biči, klešče, ogenj, železo ali različne vrste

Vergilij, Eneida 6.625-627; prevod Fran Bradač.

O Flakcinu in Priscilijanu ni znanega nič, Sosijan Hierokles, znan tudi kot filozof in pisec, je bil vikar dieceze Oriens, upravitelj (praeses) province Bitinije in v letih 310/311 prefekt Egipta (podrobneje Kuhof, Diokletian, 271-272, z bibl.). 
mučenja: nobena sila ti ni mogla odvzeti vere in ponižne vdanosti. (9) To zares pomeni biti učenec Boga, pravi Kristusov vojak, ki ga noben sovražnik ne more premagati, noben volk ugrabiti iz nebeškega tabora, nobena past preslepiti, nobena bolečina streti in nobeno trpljenje zlomiti. (10) Slednjič, po tistih devetih slavnih bitkah, v katerih si premagal hudiča, se ta ni več drznil spopasti s tabo, saj je v tolikih spopadih izkusil, da te ne more premagati. (11) Ko ti je bil pripravljen venec zmage, ${ }^{42}$ je nehal izzivati, da ga ne bi takoj vzel; in čeprav ga do sedaj še nisi prejel, je zaradi tvojih vrlin in zaslug ostal nedotaknjen v Gospodovem kraljestvu. Toda vrnimo se k vrstnemu redu dogodkov.

[17] (1) Potem ko je zagrešil ta zločin, se je Dioklecijan - sreča ga je takrat že zapustila - nemudoma napotil v Rim, da bi proslavil vicenalije, ${ }^{43} \mathrm{ki}$ so bile na dvanajsti dan pred decembrskimi kalendami [20. novembra 303]. (2) Po opravljenih prazničnih slovesnostih je nestrpen in jeznega duha odhitel iz mesta, ker ni mogel prenašati svobode rimskega ljudstva, čeprav so se že bližale januarske kalende, ko bi lahko prevzel deveti konzulat. (3) Niti trinajst dni ni mogel zdržati, da bi konzulat prevzel $\mathrm{v}$ Rimu raje kot $\mathrm{v}$ Raveni, ampak je odpotoval sredi največje zime in zaradi mraza in dežja dobil neko lažjo bolezen, ki pa je bila dolgotrajna; trpel je celo pot in $\mathrm{v}$ glavnem potoval $\mathrm{v}$ nosilnici. (4) Tako je minilo vse poletje [leta 304], ko je na poti ob obali Donave prispel v Nikomedijo, bolezen se je takrat že precej poslabšala; čeprav je videl, da ga zelo muči, se je vendar dal prinesti v javnost, da bi posvetil dirkališče, ki ga je zgradil leto dni po izpolnitvi vicenalij. (5) Potem ga je zajela taka onemoglost, da so pri vseh bogovih prosili za njegovo življenje, dokler ni na decembrske ide [13. decembra 304] nenadoma nastopilo žalovanje v palači, žalost in solze uradnikov, strah in tišina po celotnem mestu. (6) Govorilo se je, da je ne samo umrl, ampak da je bil že tudi pokopan; toda naslednje jutro se je razširil glas, da je živ, obrazi domačih in uradnikov so zasijali. (7) Ni manjkalo takih, ki so sumili, da njegovo smrt skrivajo, dokler ne pride cezar, zato da se vojaki ne bi uprli. (8) Ta sum se je okrepil in nihče več ni verjel, da je živ, dokler se ni na marčevske kalende [1. marca 305] pojavil v javnosti, komaj prepoznaven, ker ga je skoraj celo leto mučila bolezen. 1.1).

43

Mučenci so prejeli venec zmage po svoji smrti od Boga v nebesih (gl. Mort. pers.

Dvajsetletnico vladavine. Praznovanje nastopa vladavine (»rojstvo cesarja «) so obhajali vsakih pet let v Rimu, slovesnosti so trajale cel mesec. Morda je dejansko prišlo do nesoglasij med Dioklecijanom na eni in senatom in rimskim ljudstvom na drugi strani, morda so bile cesarjeve zahteve, recimo adoratio, preveč - ali pa slovesnosti premalo - razkošne (Städele, Laktanz, 130-131). 
(9) Na decembrske ide [13. decembra 304], potem ko se ga je že lotila nekakšna premrlost, podobna smrti, si je ponovno opomogel - vendar ne povsem. Postal je duševno bolan, tako da je bil kdaj povsem brez razuma, kdaj pa je spet prišel $\mathrm{k}$ zavesti.

[18] (1) Nekaj dni kasneje je prispel cezar [Galerij], ne zato, da bi čestital očetu, ampak da bi ga prisilil k sestopu z oblasti. Nedavno se je sprl s starejšim Maksimijanom in ga prestrašil z možnostjo državljanske vojne. (2) Dioklecijana je najprej napadel obzirno in prijateljsko, češ da je že star in ne najbolj zdrav, da ni več sposoben vodenja cesarstva in da se mora po velikih naporih odpočiti. Hkrati mu je omenjal tudi primer Nerve, ki je oblast predal Trajanu..$^{44}$ (3) Ta [Dioklecijan] pa je odgovarjal, da bi bilo po eni strani neprimerno, če bi se po sijaju visokega položaja spustil v temo običajnega življenja, po drugi pa bi bilo to tudi zelo nevarno, saj si je med tako dolgo vladavino nakopal sovraštvo mnogih. (4) Nerva je vladal samo eno leto in ker bremena in tolikerih skrbi zaradi starosti ali neizkušenosti ni mogel prenašati, je krmilo države izpustil iz rok in se vrnil $\mathrm{v}$ zasebno življenje, $\mathrm{v}$ katerem je nato ostarel. Če pa bi on [Galerij] želel doseči naslov cesarja (avgusta), ni nobene ovire, da se ne bi za avguste poimenovali vsi. (5) Ta pa, ki je že gojil upanje, da bo postal vladar vsega sveta, je po ugotovitvi, da mu menjava razen naslova ne bo prinesla ničesar ali ne prav veliko, odgovoril, da se mora trajno ohraniti njegova [Dioklecijanova] ureditev, po kateri morata biti v državi dva višja cesarja, ki vladata, in dva nižja, ki pomagata; med dvema je slogo ohraniti lažje, med štirimi enakimi pa nikakor. (6) Če [Dioklecijan] ne bi želel odstopiti, bo moral on sam [Galerij] poskrbeti, da ne bo več na nižjem položaju ali zadnji. Preteklo je že petnajst let, odkar je bil poslan v Ilirik, to je na obrežje Donave, da bi se boril z barbarskimi ljudstvi, medtem ko so drugi udobno vladali nad večjimi in mirnejšimi deželami. (7) Ko je utrujeni starec to slišal, potem ko je že prejel pisma starega Maksimijana, $\mathrm{v}$ katerih je ta napisal to, kar je mlajši govoril, in tudi, da ta že povečuje svojo vojsko, je v solzah rekel: »Naj bo tako, če ti to ugaja«.

(8) Preostalo je še to, da bi na skupnem posvetu vseh [cesarjev] izbrali cezarje.

"Zakaj je potreben posvet, če morata druga dva sprejeti to, kar narediva midva?"

»Res je tako. Imenovati pa morava njuna sinova.»

44 Nerva je vladal od 18. septembra 96 do 27. januarja 98. Konec oktobra 97 je adoptiral Trajana, ki je postal njegov sovladar s statusom cezarja. 
Maksimijan [starejši] je imel sina Maksencija, ${ }^{45}$ (9) ki je bil zet mladega Maksimijana [Galerija], človeka pogubne in zle narave, tako ošabnega in kljubovalnega, da ni spoštoval niti očeta niti tasta in ga zato ni maral nobeden od njiju. (10) Tudi Konstancij je imel sina Konstantina, ${ }^{46}$ odličnega mladeniča, ki je bil najbolj vreden tega dostojanstva. Njegov postavni videz, vojaška vztrajnost, dobra narava in redka prijaznost so mu priskrbeli priljubljenost pri vojakih in naklonjenost navadnih ljudi. Takrat je bil v Nikomediji in ga je Dioklecijan že zdavnaj imenoval za tribuna prvega reda.

(11) »Kaj naj se torej zgodi?«

»Ta [Maksencij] ni primeren, «je rekel [Galerij]. »Če me prezira, ko nima oblasti, kaj bo storil šele takrat, ko jo bo prevzel?«

»Ta pa je priljubljen in bo vladal tako, da bo veljal za boljšega in prizanesljivejšega od svojega očeta.«

»Tako bi se zgodilo to, da ne bom mogel narediti, kar bi želel. Imenovati je treba dva taka, ki bosta pod mojo oblastjo, ki se bosta bala in ki ne bosta storila ničesar drugače kot na moj ukaz.«

(12) »Koga bova torej imenovala?«

$»$ Severa, $\aleph^{47}$ je odgovoril ta.

»Tistega plesalca, vdanega pijači, ki mu je noč za dan in dan za noč?»

»Vreden je tega, ker se je izkazal kot zvest vojaški poveljnik in ker sem ga že poslal Maksimijanu, da ga poduči."

(13) »Naj bo tako. Koga predlagaš kot drugega?«

»Tega,« je rekel in pokazal na mladega Daja, nekega mladeniča polbarbarskega izvora, za katerega je nedavno zahteval, da se po njegovem [Galerijevem] imenu poimenuje za Maksimina. Kajti tudi njemu samemu je Dioklecijan delno zamenjal ime, zaradi znamenja, ker mu je Maksimijan [starejši] s posebno zanesljivostjo izkazoval zvestobo.

Maksencij je postal cezar 28. oktobra 306, avgust pa spomladi 307 (verjetno aprila). Njegovo cesarsko ime je bilo Mark Avrelij Valerij Maksencij (zanj gl. Donciu, L'empereur Maxence, posebej poglavje o virih, 10-38).

46 Konstantin se je rodil 27. februarja 272 ali $273 \mathrm{v}$ Naisu. Za avgusta je bil imenovan 25. julija 306 v Eburaku, današnjem Yorku, od takrat se je imenoval Gaj Flavij Valerij Konstantin. Poleg Evzebijeve biografije je o njem ohranjen tudi spis Origo Constantini neznanega avtorja, ki se po izdajatelju imenuje Anonymus Valesiani 1 (komentirana izdaja König, Origo Constantini). Za Konstantinovo dobo gl. Puech, Constantin (2011) in Giardina, L'»epoca « di Constantino, 29-48. Za sodbo o Konstantinu pri krščanskih piscih 4. in 5. stoletja, ki nikakor ni samo pozitivna, gl. Maver, Religiosi et profani principes, 156-171.

47 Sever je bil nizkega rodu in je izviral iz Ilirika. Za cezarja je bil imenovan 1. maja 305, za avgusta pa poleti (avgusta) 306. Njegov cesarsko ime je bilo Flavij Valerij Sever. 
(14) »Kdo je ta, ki ga ponujaš,« [je vprašal Dioklecijan.]

»Moj sorodnik,« je odgovoril.

Oni pa je zamrmral: „Človeka, ki mi ju ponujaš, nista vredna, da bi jima predali skrb za državo.«

»Preizkusil sem ju že,« je rekel.

»Potem moraš paziti, ker boš ti prevzel upravljanje države. (15) Jaz sem delal dovolj in skrbel za to, da je pod mojo vladavino država ostala neokrnjena. Če se bo zgodilo kaj slabega, to ne bo moja krivda.«

[19] (1) Potem ko je bilo tako sklenjeno, sta na majske kalende [1. maja 305] to tudi izpeljala. Vsi so opazovali Konstantina, nobenega dvoma ni bilo; prisotni vojaki in najuglednejši iz vojske, ki so bili izvoljeni in poklicani iz legij, so bili pozorni samo nanj, nad njim so bili navdušeni, želeli so, da bi bil izbran, in se zanj zaobljubljali bogovom. (2) Okrog tri tisoč korakov iz mesta je bil hrib, na vrhu katerega je tudi sam Maksimijan prejel škrlat, tam je bil steber z Jupitrovim kipom. Odšli so tja. (3) Sklican je bil zbor vojakov. Starec je v solzah nagovoril vojake. Sam da je že bolehen, po naporih si želi počitka, vladanje želi prepustiti bolj zdravim in imenovati druge za cezarje. Vsi so v napetem pričakovanju opazovali in čakali, kaj se bo zgodilo. (4) Tedaj je nenadoma razglasil Severa in Maksimina ${ }^{48}$ za cezarja; vsi so ostrmeli. Konstantin je stal zgoraj na tribunalu; spraševali so eden drugega, če je Konstantin morda spremenil ime, ko je vpričo vseh Maksimijan [Galerij] odrinil Konstantina, iztegnil roko nazaj, potegnil naprej [Maksimina] Daja in ga, potem ko si je slekel zasebno oblačilo, postavil na sredino. Vsi so se čudili, kdo je in od kod. (5) Ob vznemirjenju zaradi nepričakovane novosti si ni nihče drznil ugovarjati. Temu je Dioklecijan nadel svoj škrlat, ki ga je prej odložil in ponovno postal Diokles. (6) Potem so sestopili, stari »kralj« se je na vozu skozi mesto odpeljal ven in v domovino. Daja, ki je šele pred kratkim zapustil drobnico in gozdove, je hitro postal ščitonoša, kmalu zatem telesni stražar, nato tribun in že naslednji dan cezar. Prejel je Vzhod, da ga bo tlačil in zatiral, in je kot nekdo, ki ne ve ničesar o vodenju vojne in o vodenju države, postal pastir - ne črede, ampak vojakov.

[20] (1) Maksimijan [Galerij] je potem, ko sta bila izrinjena oba [cesarja] starca, dosegel, kar je želel, počutil se je kot edini gospodar vsega sveta, kajti Konstancija, čeprav ga je bilo treba imenovati prvega, je preziral, ker je bil po naravi blag in ga je oviralo telesno zdravje. (2)

48 Maksimin Daja je bil prav tako kot ostali tetrarhi izkušen vojaški poveljnik, preden je bil v Nikomediji povzdignjen v cezarja za diecezo Oriens. Od takrat naprej se je imenoval Galerij Valerij Maksimin. V avgusta je bil povzdignjen verjetno 1. maja 310. 
Upal je, da bo v kratkem umrl; če pa ne bi umrl, bi ga bilo mogoče zlahka odstraniti tudi proti njegovi volji. Kaj naj bi namreč storil, če bi ga trije prisilili odložiti oblast? (3) Sam je imel starega prijatelja Licinija, $s$ katerim sta prijateljevala od zgodnje vojaške službe, tega je spraševal za nasvet pri vseh poslih. Toda ni ga želel imenovati za cezarja, da mu ga ne bi bilo treba imenovati »sin «, zato da bi pozneje namesto Konstancija lahko njega imenoval za avgusta in brata. (4) Takrat bi bil zares prvi in bi lahko po svoji volji tolkel po vsem svetu, dokler ne bi slavil vicenalij in bi se, potem ko bi imenoval za cezarja svojega sina, ki je imel takrat devet let, sam odpovedal oblasti. Tako bi se, ko bosta Licinij $^{49}$ in Sever prevzela vrhovno vodenje cesarstva, Maksimin [Daja] in Kandidijan ${ }^{50}$ pa dobila položaj nižjih cezarjev, obkrožil z neosvojlijivim zidom, za katerim bi lahko preživel varno in mirno starost. (5) Sem so bile usmerjene njegove namere. Toda Bog, ki si ga je naredil za sovražnika, je vse njegove zamisli izničil.

[21] (1) Potem ko se je polastil najvišje oblasti, se je obrnil k tlačenju sveta, ki ga je naredil sebi dostopnega. (2) Kajti po zmagi nad Perzijci, ki imajo običaj in navado, da se suženjsko podrejajo svojim kraljem, njihovi kralji pa ljudstvo uporabljajo kot lastne sužnje, je ta malopridnež isto želel uvesti tudi v rimskem svetu. Od svoje zmage naprej je ta običaj brez sramu hvalil. (3) Ker tega ni mogel ukazati povsem očitno, je delal na način, da je ljudem odvzemal svobodo. Najprej je ukinil pooblastila magistratom. Na mučenje je poslal ne samo dekurione,,$^{51}$ pač pa tudi najuglednejše ljudi po mestih, ki so imeli naziv egregii in perfectissimi, tudi če je bilo to v zelo majhnih in civilnih pravdah. Če se je zdelo, da si zaslužijo smrt, so bili postavljeni križi, za manjše prekrške pa so bili pripravljeni okovi. (4) Svobodne in ugledne družinske matere so ugrabljali za delo v tkalnicah. Če je bilo potrebno koga bičati, so zanj $\mathrm{v}$ hlevu namestili štiri kole, na katere prej niso razpenjali niti sužnjev. (5) Kaj pa njegove zabave in užitki? Imel je medvede, ki so mu bili po velikosti povsem podobni, v času svoje vladavine jih je zbiral po celotni državi. Ko se je želel zabavati, je poimensko izbral enega in ga ukazal privesti. (6) Tem je metal ljudi, ne da bi jih pojedli takoj, ampak postopoma; ko so bili njihovi udje raztrgani, se je sladko smejal, nikoli ni obedoval brez človeške krvi. Za tiste brez uglednega položaja

Licinij je bil v avgusta povzdignjen 11. novembra 308 na posvetu tetrarhov v Karnuntu. Od takrat naprej se je imenoval Gaj Valerij Licinijan Licinij. Cesar je bil do abdikacije 19. septembra 324, umrl je zgodaj leta $325 \mathrm{v}$ Tesaloniki. Kandidijan je bil Galerijev sin, rojen ok. 296. Bil je zaročen s hčerko Maksimina Daje, leta 313 ga je ubil Licinij. 
je bila kazen ogenj. (7) To vrsto kazni je najprej dovolil uporabiti proti kristjanom, izdal je odredbe, naj jih po mučenju sežgejo ob počasnem ognju. (8) Ko so jih močno privezali, so jim pod noge polagali majhen ogenj, samo toliko, da so se jim zaradi vročine skrčila in popokala stopala in se ločila od kosti. (9) Zatem so prižigali in ugašali bakle in jih izmenično pristavljali vsem udom, tako da nobeno mesto na telesu ni ostalo nepoškodovano. Istočasno so jim obraz polivali s svežo vodo in jim namakali usta, da zaradi izsušitve grla ne bi prehitro umirali. (10) To se je ob celodnevnem žganju kože, potem ko je moč ognja prodrla do notranjih organov, končno tudi zgodilo. (11) Takrat so naredili grmado, na kateri so sežgali že ožgana telesa. Zbrane kosti so zmleli v prah in vrgli v reke ali v morje.

[22] (1) Kar se je naučil pri mučenju kristjanov, je iz same navade izvajal pri vseh. (2) Pri njem ni bila nobena kazen lahka; ne otok, ne zapor, ne rudnik - pač pa ogenj, križ in divje zveri so bile pri njem vsakodnevne in zlahka prisojene kazni. (3) Služabnikom in uradnikom je bilo za opomin dosojeno vroče železo. $V$ smrtnih obsodbah je bila smrt z mečem dodeljena le maloštevilnim, kot neke vrste privilegij, če so si zaradi starih zaslug izprosili lažjo smrt. (4) V primerjavi s povedanim je naslednje povsem nedolžno - ugasnilo je govorništvo, zagovorniki so bili odstranjeni, pravniki pregnani ali pobiti. Književnost je sodila med pokvarjene umetnosti in tisti, ki so jo poznali, so bili razglašeni za sovražnike, pregnani in iztrebljeni. Zakoni so bili ukinjeni, pri vsem je vladala samovolja, ki je bila dovoljena tudi sodnikom. V province so brez pomočnikov pošiljali sodnike iz vojaškega stanu brez kakršnekoli izobrazbe.

[23] (1) Prava nesreča za državo in vsesplošna žalost pa je bil davek, ki je bil hkrati naložen provincam in mestom..$^{52}$ Pobiralci davkov so bili razposlani na vse strani in so izterjevali vse, tako da se je zdelo, kot da gre za napad sovražnika in grozljive ugrabitve. (2) Polja so bila izmerjena do zadnje grude, trte in drevesa prešteta, živali vseh vrst popisane, zabeleženo je bilo tudi število ljudi. V mestih so se združili mestni in podeželski prebivalci, vsi trgi so bili napolnjeni z družinami, vsak je prišel z otroki in sužnji, mučilne naprave in biči so ječali, sinovi so se obešali sami vpričo staršev, najbolj vdani sužnji so pričali proti gospodarjem, žene proti možem. (3) Ko bi zmanjkalo vsega drugega, so ljudi z mučenjem silili, da so pričali proti sebi, in ko je bolečina zmagovala, so jim pripisovali še to, česar sploh niso imeli. (4) Nobenega opravičila ni bilo zaradi starosti ali slabega zdravja, privedeni so bili bolni in nemočni, pri vsakem so ocenili starost, otrokom so leta 
dodajali, starcem odvzemali. Vse je bilo prežeto z žalostjo in trpljenjem. (5) To, kar so Stari nekoč počeli premaganim po vojnem pravu, si je on [Galerij] drznil proti Rimljanom in podvrženim ljudstvom, ker so bili njegovi predniki podvrženi cenitvi, ki jo je zmagoslavni Trajan izvedel kot kazen za vedno uporne Dačane. ${ }^{53}$ (6) Od takrat se je davek pobiral po glavi in vsota se je plačevala tudi za življenje posameznikov. ${ }^{54} \mathrm{Niso}$ zaupali istim cenilcem, ampak so pošiljali vedno nove, ene za drugimi, da bi ti odkrili še več, dajatve so bile vedno podvojene, ne zato, ker bi našli več, ampak zato, da bi po svoji volji dodajali in da se ne bi zdelo, kako so bili poslani zaman. (7) Medtem se je zmanjševalo število živali, ljudje so umirali, a niti od umrlih niso prenehali pobirati dajatev, tako da ni bilo dovoljeno zastonj niti živeti niti umreti. Ostali so samo še reveži, od katerih ni bilo mogoče izterjati ničesar; pred vsemi vrstami krivic sta jih ščitila njihova beda in nesreča. (8) Vendar se je ta milostljivi človek usmilil tudi njih, da ne bi trpeli pomanjkanja. Ukazal jih je zbrati, na ladjah odpeljati na morje in potopiti. Kako usmiljen človek, poskrbel je, da nihče ne bi bil revež, ko je sam vladal! (9) Ker je pazil, da se ne bi kdo z lažmi izognil davkom, je v nasprotju z vsemi zakoni človeškosti pobil množico resnično revnih.

[24] (1) Že se mu je približala božja sodba, nastopil je čas, ko so njegove reči začele razpadati in se rušiti. (2) Ni še razmišljal o tem, da bi strmoglavil ali pregnal Konstancija, ker je bil zaposlen s stvarmi, ki sem jih zgoraj predstavil; pričakoval je njegovo smrt, vendar ni verjel, da bo umrl tako hitro. (3) Ko je bil zelo bolan, mu je pisaril, da naj mu pošlje sina Konstantina, ki ga že dolgo ni videl. (4) Ta [Galerij] pa si ničesar ni želel manj. Mladeniča je namreč pogosto zahrbtno napadal, saj si proti njemu odkrito ni upal ukreniti ničesar zaradi nevarnosti državljanske vojne in tega, česar se je najbolj bal, da bi vzbudil sovraštvo vojakov. Pod pretvezo vadbe in zabave ga je izpostavljal boju z divjimi zvermi. (5) Toda vse to je bilo zaman, kajti človeka je varovala božja roka. V skrajni nevarnosti ga je Bog osvobodil iz njegovih rok. Po številnih prošnjah, ko tega ni več mogel zavračati, je [Galerij Konstantinu] izročil pismo in ukazal, naj odpotuje naslednje jutro po prejemu ukazov, bodisi da ga

Po zmagi nad Dačani leta 106 je Trajan zasegel ogromen vojni plen in Dačanom naložil velike dajatve.

54 Med Dioklecijanovimi reformami je bil temeljite prenove deležen tudi davčni sistem. Najpomembnejši davek je bila annona, dajatev v naravi, ki so jo morali letno oddajati zemljiški posestniki in je služila preskrbi vojske. Po načinu izterjave se imenuje tudi capitatio-iugatio. Od 297 davčni seznami niso zajemali le zemlje, temveč tudi ljudi. Senatorji so poleg tega plačevali še collatio glebalis in kot izredni davek njihovega stanu aurum oblaticium (gl. Demandt, Die Spätantike, 68). 
je v resnici nameraval brez razloga zadržati - ali pa pred njim poslati Severu pismo, naj ga pridrži. (6) Ko je on [Konstantin] to spregledal, se je, medtem ko je cesar po večerji počival, v naglici odpravil na pot in pobegnil tako, da je iz številnih obcestnih postaj odpeljal vse javne konje. (7) Naslednji dan je cesar nalašč podaljšal spanec do poldneva in ga [Konstantina] dal poklicati. Rekli so mu, da je odpotoval takoj po večerji. Takrat je začel besneti in kričati. Zahteval je javne konje, da bi ga pripeljal nazaj. Sporočili so mu, da je državna poštna služba povsem brez konj. Komaj je zadrževal solze. (8) Oni [Konstantin] pa je z neverjetno naglico prispel k očetu, ki je že umiral. Priporočil ga je vojakom in mu predal oblast. Tako je Konstancij umrl na svojem ležišču, kot si je vedno želel.55 (9) Po prevzemu cesarske oblasti ni Konstantin Avgust storil ničesar, preden ni kristjanom dopustil vrnitve $\mathrm{k}$ veri in $\mathrm{k}$ njihovemu Bogu. To je bil njegov prvi ukrep pri obnovi svete vere.

[25] (1) Nekaj dni pozneje so k podli zveri [Galeriju] prinesli njegovo [Konstantinovo] z lovorom okrašeno podobo. ${ }^{56}$ Dolgo je razmišljal o tem, ali naj jo sprejme. (2) Malo je manjkalo, pa bi sežgal njo in tistega, ki jo je prinesel, vendar so ga od tega besnega dejanja odvrnili prijatelji, ki so ga opomnili na nevarnost, da bi vsi vojaki, ki so jim bili kot cezarji določeni povsem neznani ljudje, podprli Konstantina in se mu pridružili, če bi prišel z oboroženo silo. (3) Tako je podobo sprejel, čeprav nerad, in mu poslal škrlat, da bi se zdelo, kot da ga je sam imenoval za sovladarja. (4) $S$ tem so propadle njegove namere, saj poleg obstoječega števila ni mogel imenovati dodatnega (avgusta), kot je to želel. (5) Kljub temu se je domislil, da je Severa, ki je bil po letih starejši, imenoval za avgusta, Konstantina pa ne za cesarja (avgusta), kar je pravzaprav že bil, ampak za cezarja ob Maksiminu, da bi ga z drugega mesta postavil na četrto.

[26] (1) Zdelo se je, da so se zanj stvari nekako uredile, ko so mu iznenada prinesli drugo strašno novico, da je njegov zet Maksencij v Rimu postal cesar. Vzrok tega prevrata je bilo naslednje. (2) Potem ko je [Galerij] sklenil z uvedbo davka na imetje oropati svet, je šel v svojem norenju tako daleč, da ni hotel od tega izvzeti niti rimskega ljudstva. $\mathrm{V}$ Rim so že poslali cenilce, da bi popisali ljudstvo. (3) Skoraj istočasno je ukinil vojašnico pretorijancev v Rimu. Tako so maloštevilni vojaki,

$$
\begin{aligned}
& \text { osebnostim portret v obliki doprsnega kipa iz voska ali naslikan na ploščo. Te } \\
& \text { upodobitve so služile hkrati tudi kot predloge za kipe, novce in podobno. S } \\
& \text { sprejetjem škrlatnega plašča je Galerij priznal Konstantina za člana vladarskega } \\
& \text { kolegija (Städele, Laktanz, 158-159). }
\end{aligned}
$$

Konstancij je umrl 25. julija 306 v Eburaku v Britaniji za neko boleznijo.

Ob nastopu vladavine je novi cesar poslal svojim socesarjem in drugim visokim osebnostim portret v obliki doprsnega kipa iz voska ali naslikan na ploščo. Te odobitve so služile hkrati tudi kot predloge za kipe, novce in podobno. S kolegija (Städele, Laktanz, 158-159). 
ki so v Rimu ostali v vojašnici, zgrabili priložnost ter pobili uradnike, kar se ni zgodilo proti volji ljudstva, ki je bilo že vznemirjeno, in Maksencija oblekli v škrlat. (4) Ta novica o nepričakovanih dogodkih je Galerija nekoliko vznemirila, vendar ne preveč prestrašila. Sovražil je tega človeka [Maksencija], treh cezarjev pa ni mogel imenovati. Zdelo se mu je dovolj, da je že enkrat storil to, česar ni hotel.

(5) Poklical je Severa in ga spodbudil, da bi sprejel cesarsko oblast. Z Maksimijanovo vojsko ga je poslal v boj z Maksencijem in v Rim. Tam pa so njegove vojake že večkrat pričakali z dobrodošlico, tako da mestu niso sklenili le prizanesti, ampak so si želeli tam tudi živeti. (6) Maksencij se je zavedal svojega zločina in čeprav bi po dednem pravu lahko pridobil na svojo stran očetove vojake, je premišljeval o možnosti, da bi tast Maksimijan, ki se je bal ravno tega, pustil Severa v Iliriku in se sam prišel spopast z njim. Iskal je način, kako bi se zavaroval pred grozečo nevarnostjo. (7) Svojemu očetu [Maksimijanu], ki je potem, ko je odložil oblast, živel v Kampaniji, je poslal škrlat in ga drugič imenoval za avgusta. Ta pa si je želel spremembe in ker je oblast odložil proti svoji volji, jo je zdaj rade volje sprejel. (8) Sever je šel potem naprej in je z vojsko prispel pred mestno obzidje. Vojaki pa so takoj odvrgli svoja bojna znamenja in se predali tistemu, proti kateremu so prišli. (9) Kaj je preostalo zapuščenemu drugega kot beg? Proti njemu je že prihajal Maksimijan, ki je ponovno prevzel oblast, ob njegovem prihodu se je zatekel $v$ Raveno in se tja zaprl z maloštevilnimi vojaki. (10) Ko je videl, da bo izročen Maksimijanu, se mu je predal in škrlatno oblačilo izročil tistemu, od katerega ga je prejel. (11) S tem je dosegel zgolj pravico do blažje smrti. Kajti bil je prisiljen umreti počasi, $\mathrm{z}$ odprtimi žilami.

[27] (1) Herkulij, ki je poznal Maksimijanovo [Galerijevo] norost, je začel razmišljati o tem, kako ga bo novica o Severovi smrti razjezila, da bo prišel z vojsko; mogoče se mu bo priključil tudi Maksimijan z dvojnimi četami, ki se jim ne bi mogel postaviti po robu. Po utrditvi mesta in skrbnih pripravah je odpotoval v Galijo, da bi na svojo stran pridobil Konstantina, ko bi mu dal mlajšo hčer za ženo. (2) Ta [Galerij] je medtem z zbrano vojsko napadel Italijo ter prispel do mesta $\mathrm{z}$ namero uničiti senat in pobiti ljudstvo, vendar so bili vsi dostopi zaprti in utrjeni. Upanja na vdor ni bilo, napad bi bil težak, za obleganje obzidja je bilo čet premalo. Ker ni Rima še nikoli videl, je menil, da ni veliko večji od ostalih mest, ki jih je poznal. (3) Tedaj so se nekatere legije prestrašile zločina, v katerem bi tast napadel zeta in rimski vojaki Rim, odvrgli so bojna znamenja in zapustili njegovo poveljstvo. (4) In ko so podvomili tudi drugi vojaki, se je njegova [Galerijeva] ošabnost zlomila, zapustil ga je pogum in se je, boječ se Severovega konca, vrgel pred vojake na 
tla in jih prosil, naj ga ne izročijo sovražniku, dokler jih ni z velikimi obljubami uspel pridobiti. Potem se je obrnil in začel naglo bežati, pri čemer bi ga bilo zlahka mogoče ujeti, tudi če bi mu kdo sledil le z maloštevilno vojsko. (5) Ker se je tega bal, je vojakom dovolil, da se čimbolj razpršijo, plenijo in uničujejo, tako da bi zasledovalci ostali brez oskrbe. (6) Tisti del Italije, kjer se je gibala ta kužna vojska, je bil povsem izropan, žene napadene, device oskrunjene, očetje in možje mučeni, da bi predali svoje hčere, žene in imetje. Drobnico in živino so odpeljali kot plen, odvzet barbarom. (7) Na tak način se je vrnil na svoje območje nekdanji rimski cesar, sedaj ropar Italije, vse je opustošil kot kak sovražnik. (8) Ko je prejel cesarsko čast, se je razglasil celo za sovražnika rimskega imena, hotel ga je spremeniti, da se ozemlje ne bi več imenovalo »rimsko«, ampak »dačansko« cesarstvo.

[28] (1) Po njegovem [Galerijevem] begu se je drugi Maksimijan vrnil iz Galije in vladal skupaj s sinom [Maksencijem]. Toda do mladega je bila pokornost večja kot do starca, ker je sin oblast prejel prej in ker je imel večjo moč, ter ker je sam vrnil oblast očetu. (2) Starec je težko prenašal, da ne more svobodno početi, kar bi si želel, in je sinu zavidal Z otroškim ljubosumjem. Razmišljal je, kako bi mladeniča odstavil in si povrnil nekdanjo moč; to se mu je zdelo enostavno, ker je imel vojake, ki so zapustili Severa. (3) Sklical je ljudstvo in vojake, kot bi želel imeti govor o slabem položaju v državi. Ko je že veliko govoril o tem, je z roko pokazal na sina in rekel, da je on izvor vsega zla in začetnik vseh nesreč, ki jih trpi država, ter mu strgal škrlat $\mathrm{z}$ ramen. (4) Ta [Maksencij] pa je slečen sestopil s tribunala, vojaki so ga sprejeli. Prestrašen zaradi njihove jeze in kričanja je bil nezvesti starec pregnan iz Rima kot drugi Tarkvinij Ošabni.

[29] (1) Po vrnitvi v Galijo, kjer se je nekaj časa mudil, je odpotoval k sovražniku svojega sina Maksimijanu [Galeriju], kot da želi z njim govoriti o ureditvi položaja v državi - v resnici pa zato, da bi ga ob priložnosti za pomiritev ubil in mu odvzel njegov del cesarstva, ker je ostal brez svojega. (2) Ko je prispel tja, je bil tam Diokles, ${ }^{57}$ ki ga je njegov zet malo pred tem poklical, da bi naredil tisto, česar ni prej, vpričo njega predal oblast Liciniju namesto Severu. Tako se je to zgodilo vpričo obeh. Na tak način jih je bilo istočasno šest [cesarjev]. (3) Namere starega Maksimijana so propadle, pripravljal se je na tretjo bitko; poln slabih misli in zločinov se je vrnil v Galijo, da bi z zvijačo

57 Dioklecijanovo ime, preden je postal cesar. Kasneje ga pisec spet imenuje Dioklecijan (Mort. per. 41.1 in 42.2). 
obkolil cesarja Konstantina, svojega zeta in zetovega sina ${ }^{58}$ - in je zato, da ne bi bil sumljiv, odložil cesarsko oblačilo. Ljudstvo Frankov je bilo pod orožjem. (4) Maksimijan je tega [Konstantina], ki ni ničesar sumil, pregovoril, da naj s sabo ne vodi svoje celotne vojske, barbare da je mogoče premagati z maloštevilnimi vojaki; tako bi sam imel vojsko, ki bi jo prevzel, njega [Konstantina] pa bi zlahka premagal zaradi maloštevilnosti vojakov. (5) Mladenič je verjel izkušenemu in starejšemu, poslušal je svojega tasta, odpravil se je tako, da je večji del vojske pustil tam. Maksimijan je počakal nekaj dni, da bi Konstantin prispel na ozemlje barbarov, nenadoma ponovno pograbil škrlat, vdrl v državno blagajno in začel darežljivo deliti, kot je bil vajen, o Konstantinu si je izmislil stvari, ki pa so potem doletele njega samega. (6) Cesarju je bilo hitro sporočeno, kaj se je zgodilo. S čudežno naglico se je vrnil z vojsko. Presenetil ga je, ko še ni bil dovolj pripravljen, in vojaki so se vrnili k svojemu cesarju.

(7) Oni [Maksimijan] je zavzel Masilijo in zavaroval vrata. Cesar se je približal in ga nagovoril, ko je stal na obzidju, vendar ne ostro in sovražno, vprašal ga je, ali je želel kaj, česar ni dobil, in zakaj počne nekaj, kar zanj ni primerno. Ta pa je z obzidja odgovoril s kletvinami. (8) Takrat so se naenkrat za njegovim hrbtom odprla vrata, vojake so spustili noter. Pred cesarja so privedli upornega avgusta, nečastnega očeta, nezvestega tasta. Poslušal je o zločinih, ki jih je storil, slekli so mu obleko in mu, potem ko so ga opomnili, podarili življenje.

[30] (1) Potem ko je izgubil časti cesarja in tasta, ni mogel prenesti ponižanja, ampak je že snoval drugo zaroto, ki jo je enkrat že nekaznovano zagrešil. (2) Poklical je svojo hčer Favsto in jo skušal s prošnjami in laskanjem pregovoriti, da bi izdala soproga, obljubil ji je drugega, uglednejšega moža. Prosil je le to, naj pusti odprta vrata spalnice in naj bo ta manj skrbno zastražena. (3) Obljubila je, da bo tako storila, in je o tem nemudoma poročala možu. Dogovorjeno je bilo, da bodo pripravili past, s katero se bo jasno pokazal zločin. Podtaknili so nekega malopridnega evnuha, ki naj bi umrl namesto cesarja. (4) Oni [Maksimijan] je vstal sredi gluhe noči, zdelo se mu je, da je vse primerno za zaroto. Stražarjev je bilo malo, pa tudi stali so bili nekoliko dlje proč; povedal jim je, da je imel sanje, ki bi jih rad povedal sinu. Vstopil je oborožen, ubil evnuha in prišel ven s hvalisavim pripovedovanjem, kaj je zagrešil. (5) Takrat se je na drugi strani pojavil Konstantin s skupino oboroženih mož. Truplo ubitega so odnesli iz spalnice, morilec, ujet pri 
dejanju, pa je obmolknil, tako kot stoji trd kamen, marpezijska stena. ${ }^{59}$ Obtožen je bil nečastnega dejanja in zločina. Dovoljeno mu je bilo izbrati način smrti in privezal je zanko visoko na tram, da nečastne bi smrti umrl. ${ }^{60}$ (6) Tako je ta največji rimski cesar, ki je po preteku daljšega obdobja $z$ veliko slavo praznoval dvajsetletnico vladavine, svoje odvratno življenje končal z grdo in sramotno smrtjo, $z$ izpahnjenim in zlomljenim ošabnim vratom.

[31] (1) Bog, maščevalec svoje vere in svojega ljudstva, je oči obrnil od tega [Maksimijana] proti drugemu Maksimijanu [Galeriju], začetniku nečastnih preganjanj, da bi tudi nad njim pokazal moč svoje veličine. Tudi ta je že sam premišljeval o praznovanju dvajsetletnice lastne vladavine. (2) Kot je že prej obremenil province $z$ davki v zlatu in srebru, jim je sedaj, da bi izpolnil obljube, v imenu praznovanj vicenalij zadal drugi udarec s sekiro. (3) Kdo bi lahko primerno opisal, kako je bil človeški rod tlačen zaradi izterjevanja dajatev, zlasti v žitu? Vojaki vseh uradov, bolje rečeno mesarji, so preganjali vsakega posameznika. Nihče ni vedel, komu je treba najprej ugoditi, za tiste, ki niso imeli ničesar, ni bilo milosti. Mnogi so morali vzdržati raznovrstna mučenja, če niso mogli dati tega, česar sploh niso imeli. (4) Obdani s številnimi stražarji niso imeli niti trenutka, da bi zajeli sapo, v nobenem delu leta niti malo počitka. Pogosto je nastal spor zaradi istih ljudi med uradniki in med vojaškimi sodniki. Nobeno območje ni bilo brez cenilcev, nobena trgatev brez nadzornika, nič ni ostalo za življenje tistim, ki so delali. Čeprav je bilo neznosno, da se je tistim, ki so hrano ustvarili s svojim delom, jemalo od ust, bi bilo to še možno prenašati, če bi se dalo upati na boljšo prihodnost. (5) Kaj pa obleke vseh vrst? In zlato? In srebro? Ali ne bi bilo teh stvari mogoče kupovati šele po prodaji pridelkov? Od kod naj vzamem, brezumni tiran, če mi odvzemaš ves pridelek in mi grobo trgaš vse, kar je šele začelo roditi? (6) Kdo ni bil oropan vseh dobrin, da bi on zbral vse blago pod svojo vladavino za proslavo, ki je kljub temu ne bo mogel praznovati? ${ }^{61}$

[32] (1) Imenovanje Licinija za cesarja [avgusta] je razjezilo Maksimina, ni hotel, da bi njega imenovali cezar ali da bi bil na tretjem mestu. (2) Zato mu je oni [Galerij] večkrat poslal odposlance in ga prosil, naj se mu ukloni, naj se drži ureditve, umakne starejšemu in izkaže čast osivelemu. (3) Ta [Maksimin Daja] je postal še predrznejši in se je skliceval na prednost glede na čas vladanja, trdil je, da mora biti on prvi, ker je prej prejel škrlat, prezrl je prošnje in ukaze dru-

60 Vergilij, Eneida 12.603, prevod Fran Bradač.

61 Napoved, da Galerij ne bo dočakal dvajsetletnice svoje vladavine. 
gega. (4) Zver [Galerij] je trpela in tulila; govoril je, da je to zahvala, ker je človeka nizkega rodu postavil za cezarja ter pričakoval, da mu bo poslušen, ta pa zdaj pozablja na te usluge in sramotno zavrača njegove želje in prošnje. (5) Premagan zaradi [Maksiminove] trme je [Galerij] popustil in odložil ime cezarja ter sebe in Licinija imenoval za avgusta, Maksimina in Konstantina pa za sinove avgustov. Zatem mu je Maksimin pisal, da bi ga obvestil, kako je bil na Marsovem polju nedavno s strani vojakov imenovan za avgusta. Galerij je to novico sprejel z žalostjo in bolečino ter ukazal, naj se vsi štirje imenujejo za cesarje [avguste].

[33] (1) Že je teklo osemnajsto leto [njegove vladavine], ${ }^{62}$ ko ga je [Galerija] Bog udaril z neozdravljivo boleznijo. ${ }^{63} \mathrm{Na}$ spodnjem delu rodil se mu je naredila nevarna rana, ki se je še razraščala. (2) Zdravniki so rezali in zdravili. Nastala je brazgotina, vendar se je rana ponovno odprla, iz strgane vene je iztekala kri že v skorajda taki meri, da je bilo ogroženo življenje. Iztekanje krvi so komaj zaustavili. Zdravljenje se je moralo začeti znova. Spet je nastala brazgotina. (3) Vendar je že rahel premik telesa rano spet odprl in izteklo je še več krvi kot prej. Bledel je in hujšal ter telesno oslabel, šele takrat se je krvavenje spet ustavilo. (4) Zdravljenje na rano ni imelo več učinka; rak je že napadel sosednje dele telesa in kolikor bolj so rezali, bolj se je širil. Kolikor bolj so zdravili, bolj se je razraščal ... učitelji stran so stopili, Hiron, Filiridov sin, in Amitaonijev Melamp. ${ }^{64}$ Od vsepovsod so privedli odlične zdravnike, vendar človeške roke niso prinesle napredka. (5) Zatekali so se k malikom, Apolona in Asklepija so naprosili za zdravilo. Apolon ga je predpisal, vendar se je bolezen še poslabšala. (6) Konec ni bil več daleč, vsi spodnji deli telesa so bili že zajeti. Zunanje razpadanje je prodiralo v notranjost, ves predel medenice je razpadal. Kljub temu ga nesrečni zdravniki niso prenehali negovati in zdraviti, čeprav brez upanja, da bi premagali bolezen. (7) Ko je zajelo notranjost, je zlo prehajalo globlje in zavzelo vse, znotraj so se zaredili črvi. Smrad se ni razširil samo po palači, temveč tudi po celotnem mestu. To ni bilo čudno, saj sta se pomešala oba telesna odvoda. (8) Razjedali so ga črvi, telo je razpadalo

62 Med 1. marcem 310 in 1. marcem 311.

63 Galerijevo bolezen omenjajo tudi Evzebij (Hist. eccl. 8.16.3-5), Zosim (Historia nova 2.11) in Anonymus Valesianus (Origo Const. 3.8). Podobna bolezen in nato smrt je doletela tudi selevkidskega vladarja Antioha Iv. Epifana leta 164 pr. Kr., o čemer piše 2. knjiga Makabejcev (9.1-12) v Stari zavezi. O podobnih smrtih drugih vladarjev, ki so bili hkrati tudi preganjalci in tirani, gl. Cook, Lactantius on the Death, 385-403.

64 Vergilij, Georgike 3.549-550. 
ob nevzdržnih bolečinah. Grozljiv krik se do zvezd je razlegal, kakšno tuljenje, ko bik že ranjen beži od oltarja. ${ }^{65}$ (9) Na razpadajoči zadnji del telesa so polagali vroče kuhano meso, da bi toplota izvlekla črve. Ko se je vse to razprlo, jih je gomazela neverjetna množina, vendar jih je zaradi razpadajočega tkiva nastajalo še več. (10) Ko se je zlo razširilo, so postajali deli telesa brezoblični. Zgornji del se je vse do rane posušil, ob strašnem hujšanju se je obledela koža usedala globoko med kosti, spodnji del telesa pa se je nasprotno napihnil, stopala so postala brezoblična. (11) To se je dogajalo vse leto, dokler ni bil ukročen zaradi bolečin končno primoran priznati Boga. $\mathrm{V}$ razmakih med napadi bolečine je kričal, da bo obnovil božji tempelj in da namerava zadostiti za svoj zločin. Ko je že umiral, je izdal naslednji odlok. ${ }^{66}$

[34] (1) »Med vsem drugim, kar smo vedno sprejeli zaradi dobrobiti in koristi države, smo doslej želeli, da bi bilo vse v skladu s starimi zakoni in rimsko družbeno ureditvijo, in skrbeli za to, da bi se tudi kristjani, ki so zapustili način življenja svojih prednikov, vrnili k zdravemu razumu. (2) Iz nekega vzroka je te kristjane popadla tolikšna samovolja in tolikšna norost, da niso več sledili uredbam starih, ki so jih uvedli morda ravno njihovi predniki, temveč so po svoji volji, ko se jim je zljubilo, sebi ustvarili zakone, katerim so se podredili, in so z vseh strani zbrali pripadnike različnih ljudstev. (3) Ko smo izdali ukaze, da se je treba vrniti k starim uredbam, so se številni izpostavili nevarnosti, mnogi so tudi umrli. (4) Ker so številni vztrajali v svojih prepričanjih in ker smo uvideli, da ne opravljajo obredov bogovom niti ne izvajajo obredov, ki bi jih morali, ter ne častijo krščanskega Boga, smo z mislijo na svojo najmilejšo prizanesljivost in večno navado, po kateri smo navajeni vsem ljudem stalno izkazovati milost, menili, da jim moramo oprostiti. Tako naj bodo spet kristjani in naj obnovijo svoja shajališča, s tem da ne smejo početi ničesar proti ureditvi države. (5) V drugem pismu bomo uradnikom napisali, katere ukrepe naj izvajajo. Sledeč tej naši oprostitvi morajo svojega Boga prositi za zdravje nas, države in sebe, tako da bo država obvarovana $\mathrm{z}$ vseh strani in da bodo lahko varni živeli na svojih domovih.«

[35] (1) Ta edikt je bil objavljen v Nikomediji dan pred majskimi kalendami v času osmega Galerijevega in petega Maksiminovega

65 Vergilij, Eneida 2.222-224.

66 Besedilo Galerijevega tolerančnega edikta v grškem prevodu navaja Evzebij (Hist. eccl. 8.16.1 in 8.171-1). Za edikt prim. podrobneje Kuhoff, Diocletian, 871881, Marcone, Editto di Galerio, Bratož, Forma e contenuto, 25-46, in Brandt, Galerio legislatore, 17-24. 
konzulata. ${ }^{67}$ (2) Po odprtju ječ si bil takrat osvobojen ti, najdražji Donat, skupaj z ostalimi izpovedovalci vere, potem ko je bila ječa šest let tvoj dom. (3) On [Galerij] pa zaradi tega dejanja ni prejel milosti od Boga, temveč je po nekaj dneh, potem ko je priporočil Liciniju svojo ženo in sina ter ju izročil v njegove roke, ko so mu razpadli že skoraj vsi udje, umrl zaradi grozljive bolezni. ${ }^{68}$ (4) To se je v Nikomediji razvedelo sredi istega meseca, ko naj bi na marčeve kalende praznovali njegove vicenalije. ${ }^{69}$

[36] (1) Ob tej novici ${ }^{\circ 0}$ je z Vzhoda pohitel Maksimin, tako da je vzpostavil obcestne postaje $\mathrm{z}$ namenom zavzeti province in je - medtem ko se je Licinij še mudil - zavzel vse ozemlje do Halkedonske soteske. ${ }^{71}$ Vdrl je v Bitinijo, kjer je takoj pripomogel k svoji priljubljenosti, ko je na veliko veselje vseh ukinil davek. (2) Med obema cesarjema je takrat nastal spor in skorajda vojna. Nasprotni obali sta zasedla z vojsko, vendar sta pod določenimi pogoji sklenila mir in prijateljstvo in $\mathrm{v}$ isti soteski potrdila zvezo s stiskom desnice. (3) Oni [Maksimin] se je brezskrbno vrnil ter v Siriji in Egiptu počel enako kot prej. Najprej je ukinil splošno pomilostitev kristjanov, ki je bila izdana, in spodbudil poslanstva mest, naj zahtevajo, da se kristjanom ne dopusti ponovno graditi shajališč znotraj mest. S tem je želel doseči vtis, da je zaradi nagovarjanja drugih ukazal narediti to, kar je želel izvesti sam. (4) V soglasju z njimi je uvedel imenovanja svečenikov na nov način, po enega za posamezno mesto izmed najuglednejših meščanov, ki so morali vsakodnevno prinašati žrtve vsem njihovim bogovom, podpirati stare svečeniške službe, paziti, da kristjani ne bi gradili svojih stavb in da se ne bi zbirali ne javno ne zasebno, temveč da bi jih zajeli in jih po svojem pravu prisilili k žrtvovanjem ali izročili sodnikom..$^{72}$ (5) To mu je bilo še premalo, zato je na čelo vsake province postavil po enega svečenika izmed ljudi višjega stanu in tako enim kot drugim zapovedal, da morajo nastopati oblečeni v bela oblačila.

(6) Pripravljal se je na to, da bi storil, kar je že na Vzhodu. Ko je na zunaj kazal prizanesljivost, je božje služabnike prepovedal ubijati, vendar jih je ukazal pohabljati. (7) Tako so izpovedovalcem iztikali oči, jim sekali roke in noge ter rezali nosove ali ušesa.

67 Torej 30. aprila.

68 Galerij je bil pokopan v Romulijani (dan. Gamzigrad pri Zaječaru, Srbija), kjer so odkrili njegov mavzolej.

69 Torej 1. marca.

70 O Galerijevi smrti.

71 Mesto Halkedon v Mali Aziji nasproti Bizanca.

72 O Maksiminovih preganjanjih piše tudi Evzebij (Hist. eccl. 9, pogl. 4-6). 
[37] (1) Medtem ko je to počel, ga je [Maksimina] prestrašilo Konstantinovo pismo, zato je hlinil, da je spremenil svoje ravnanje, vendar je kljub temu tiste [izmed kristjanov], ki so mu padli v roke, dal skrivaj utopiti v morju. Tudi ni opustil navade vsakodnevnega žrtvovanja v palači. (2) Prvi je iznašel tudi to, da živali, s katerimi se je hranil, niso ubijali kuharji, temveč so jih žrtvovali svečeniki na oltarjih, tako da se na mizo ni prinašalo ničesar, od česar ne bi bil del ali celota žrtvovan ali polit $\mathrm{z}$ vinom - tako da je vsak, ki je bil poklican k pojedini, od tam odšel omadeževan in umazan. (3) V drugih zadevah je bil podoben svojemu učitelju, kajti če je še kaj ostalo ali če sta Diokles ali Maksimijan še kaj pustila, je on vse to odvzel brez kakršnegakoli sramu. (4) Tako so se zapirale zasebne žitnice, pečatila so se skladišča, davki so se izterjevali že za naslednja leta. Zaradi tega sta kljub obilnim pridelkom izbruhnili lakota in nezaslišana draginja. (5) Črede goveda in ovac so plenili za vsakodnevna žrtvovanja, s čemer je svoje bližnje tako pokvaril, da so prezirali žito. Razsipal je brez ozira in brez mere, vse svoje spremstvo, ki je bilo zelo številno, je nagrajeval z dragimi oblekami in z zlatim denarjem, navadnim vojakom in novincem je dajal srebro, barbare je počastil z darovi vseh vrst. (6) Kar je odvzemal živim, je odnašal ali podarjal svojim, ki so zahtevali tuje. Morda bi si za to zaslužil celo zahvalo, kajti po običaju prizanesljivih razbojnikov je odnašal plen brez prelivanja krvi.

[38] (1) Največji zločin, do katerega drugi [vladarji] niso prišli, je bila njegov strast do zapeljevanja. Tega ne znam imenovati drugače kot slepo in nebrzdano, vendar s temi besedami teh stvari zaradi gnusnosti ni mogoče izraziti; jezik izgublja moč zaradi velikosti zločina. (2) Evnuhi in zvodniki so stikali vsepovsod. Kjerkoli so našli kak lepši obraz, so se morali očetje in možje umakniti. Plemenitim ženam in devicam so slekli obleko in pregledali vse ude, da kak del telesa ne bi bil nevreden cesarskega ležišča. Če se je katera branila, so jo utopili v vodi, kot bi bila čistost pod njegovim zvodništvom zločin razžalitve veličanstva. (3) Nekateri so potem, ko so jim oskrunili žene, ki so jih tako častili zaradi njihove čistosti in zvestobe, ubili sami sebe, saj niso mogli prenesti bolečine. Pod to pošastjo ni bilo mogoče ohraniti nobene čistosti, če ni kaka posebna iznakaženost odvrnila barbarskega poželenja. (4) Končno je uvedel tudi navado, da se ni smel nihče poročiti brez njegovega dovoljenja, da bi bil pri vsaki poroki prvi preizkuševalec. (5) Onečaščene v svobodi rojene device je podarjal za žene svojim sužnjem. Tudi njegovi spremljevalci so pod takim vladarjem posnemali onečaščenja in nekaznovano skrunili spalnice svojih gostiteljev - kdo bi jih namreč lahko kaznoval? Hčere navadnih ljudi so lahko ugrabljali, kot se je komu zahotelo. Hčere odličnikov, ki se jih ni smelo 
ugrabljati, so zahtevali kot izraz posebnega privilegija - in če je cesar tak zahtevek podprl, ga ni bilo mogoče zavrniti, sicer bi sledila smrt ali kak barbar za zeta. (6) Kajti med njegovimi telesnimi stražarji ni bilo skoraj nikogar razen tistih, ki so jih Goti v času vicenalij pregnali s svojih zemljišč in so se predali Maksimijanu na pogubo ljudstva; tisti, ki so bežali pred barbarskim suženjstvom, so sedaj gospodovali nad Rimljani. (7) Obkrožen s takimi spremljevalci in obdan s takimi stražarji je imel Vzhod za zabavo.

[39] (1) Potem ko je uzakonil svoj razvrat tako, da je štel za pravilno vse, česar bi si zaželel, se ni zadržal niti pred avgusto, ki jo je nekoč imenoval za svojo mater. (2) Po Maksimijanovi [Galerijevi] smrti je prišla k njemu Valerija, ki je menila, da bo v njegovem delu države varnejša, še posebej zato, ker je že imel ženo. (3) Toda ta divja žival se je vnela od znotraj. Ženska je še vedno nosila črna oblačila, ker se čas žalovanja še ni iztekel, ko je že poslal odposlance, da bi jo zaprosil za roko, pri čemer je nameraval svojo ženo odsloviti. Odgovorila je pogumno, kot je znala samo ona. (4) Najprej, da ne more govoriti o poroki v žalnih oblačilih, dokler je pepel njenega moža, njegovega očeta, še vedno topel; dalje, da bi on ravnal sramotno, če bi odslovil zvesto ženo, kar bi gotovo storil tudi njej; slednjič pa ne bi bilo primerno za žensko njenega imena in stanu, če bi brez upoštevanja običajev in izročil vzela drugega moža. (5) Sporočeno mu je bilo, kaj si je drznila. Njegova strast se je sprevrgla v jezo in bes. Žensko je takoj izobčil, zasegel je njeno lastnino, ji odvzel spremstvo, dal evnuhe pobiti z mučenjem, njo samo pa $\mathrm{z}$ materjo poslal v izgnanstvo - in sicer ne na določen kraj, temveč tako, da jo je v sramoti preganjal sem in tja, njene prijateljice pa obsodil pod pretvezo prešuštva.

[40] (1) Bila je neka ženska senatorskega rodu, ki je od sinov že dobila vnuke. To je imela Valerija rada kot drugo mater; mislil je, da ga je zavrnila po njenem nasvetu. Namestniku $<\ldots>$ je naročil, naj jo sramotno ubije. (2) Njej sta bili pridruženi še dve ženski enakega položaja. Ena od njiju, ki je pustila v Rimu hčer za devico vestalko, je skrivaj prijateljevala $\mathrm{z}$ Valerijo, druga pa je imela moža senatorja in avgusti [Valeriji] ni bila posebej blizu. Obe so ubili zaradi velike telesne lepote in čednosti. (3) Ženski so nenadoma zgrabili vojaki, ne da bi jima sodili, ampak da bi se zgodil zločin; ni bilo namreč nobenega tožnika, pač pa so našli nekega Juda, ki je bil kriv drugih zločinov in je v upanju, da bo oproščen, lažno pričal proti nedolžnima. Pravični in prizadevni sodnik je odšel s stražo iz mesta, da ga ne bi kamenjali. Ta tragedija se je dogajala v Niceji. (4) Juda so zaslišali z mučenjem in je pričal, kot mu je bilo zapovedano; mučitelji pa so jima s pestmi preprečili, da bi ugovarjali. Ukazano je bilo, da obe nedolžni odpeljejo. 
To sta spremljala jok in žalovanje - ne samo moža, ki je bil ob svoji zvesti ženi, temveč vseh, ki so bili zbrani zaradi tega gnusnega in nezaslišanega zločina. (5) Da ju nezadovoljno ljudstvo ne bi iztrgalo iz rok njunih krvnikov, so ju pospremili vojaki v oklepih in lokostrelci. Tako so ju odvedli h kazni sredi čete oboroženih vojakov. (6) In ker so njune služabnike pregnali, bi tam ostali nepokopani, če ju ne bi pokopalo skrivno usmiljenje prijateljev. A tudi tisti zvodnik ni prejel obljubljene oprostitve, temveč so ga privezali na leseno rogovilo [križ] in takrat je razkril celotno skrivnost; $v$ zadnjem izdihljaju je pred vsemi pričal, da sta bili umorjeni nedolžni.

[41] (1) Avgusta je bila izgnana v samotne predele Sirije in je o tej nesreči prek tajnih slov obvestila svojega očeta Dioklecijana. (2) Ta je po poslancih prosil, da bi se hči vrnila k njemu, kar pa ni pomagalo. Prosil je znova in znova, vendar vrnitev ni bila odobrena. (3) Nazadnje je poslal nekega svojega sorodnika, vojaka in sposobnega človeka, naj ga [Maksimina] zaprosi glede na njegova [Dioklecijanova] prejšnja dobra dela. Tudi ta ni nič opravil in je sporočil, da so vse prošnje zaman. ${ }^{73}$

[42] (1) Istočasno so na Konstantinov ukaz porušili Maksimijanove kipe in postrgali slike, kjerkoli je bil upodobljen. Ker sta bila pogosto upodobljena oba starca skupaj, so hkrati odstranili podobe obeh. (2) Tako je Dioklecijan še živ videl to, kar se ni zgodilo še nobenemu cesarju, in je zaradi dvojne bolečine sklenil, da mora umreti. Iz obupa se je v bolečini metal sem in tja, ni spal in ni jedel. V stokanju, ječanju in napadih joka se je metal zdaj na ležišče in zdaj spet na tla. (3) Tako je vladarja, ki je bil dvajset let najsrečnejši, Bog ponižal do neuglednega življenja, mu zadal nesreče in ga privedel do tega, da je zasovražil življenje ter na koncu umrl zaradi lakote in tesnobe.

[43] (1) Ostal je še eden od božjih sovražnikov, Maksimin, katerega padec in pogubo bom opisal zdaj. (2) Ker je gojil zamero do Licinija, ki ga je Maksimijan [Galerij] postavil nadenj, je z njim nekaj prej sklenil prijateljstvo. Ko je slišal, da je bila Konstantinova sestra zaročena z Licinijem, je [Maksimin Daja] pomislil, da sta se dva cesarja zarotila proti njemu. (3) V tajnosti je napotil poslance v Rim, da bi z Maksencijem sklenil zavezništvo in prijateljstvo. Poslal mu je tudi prijazno pismo. Poslanci so bili prijazno sprejeti; sklenjeno je bilo prijateljstvo, kipa obeh so postavili skupaj. (4) Maksenciju se je to zdelo kot božja pomoč; že je namreč napovedal vojno Konstantinu pod pretvezo, da želi maščevati očetovo smrt. (5) Iz tega se je porodil sum, da je pogubni starec [Maksimijan] samo hlinil nesoglasja s sinom, s čimer bi

73 Avtor skuša prikazati, kako velika je bila božja kazen za Dioklecijana, ki je padel tako nizko, da ni mogel zaščititi niti svojih najbližjih. 
ostalim pripravil pot v propad in bi potem, ko bi jih vse odstranil, sebi in svojemu sinu prisvojil oblast nad celim svetom. (6) Vendar je bilo vse to popolnoma napačno. Njegova namera je bila odstraniti sina in vse ostale in ponovno ustoličiti sebe in Dioklecijana.

[44] (1) Med njima [Maksencijem in Konstantinom] se je že začela državljanska vojna. Čeprav se je Maksencij zadrževal v Rimu in mu je bilo prerokovano, da bo umrl, če se bo znašel zunaj mestnih vrat, je kljub temu vodil vojno s sposobnimi poveljniki. (2) Maksencij je imel več sil, ker je dobil od Severa vojsko svojega očeta in ker je svojo lastno pred kratkim privedel iz dežele Mavrov in Getulov. ${ }^{74}$ (3) Spopadli so se, Maksencijevi vojaki so zmagovali, nato pa se je Konstantinu povrnil pogum in je pripravljen na kakršenkoli izid vojsko pomaknil bližje do obzidja ter se utaboril nasproti Milvijskega mostu. (4) Približeval se je dan Maksencijevega prevzema oblasti, šesti dan pred novembrskimi kalendami, ki bi sklenil pet let njegove vladavine. (5) Konstantin je bil med spanjem opomnjen, da naj na ščite nariše nebeški znak Boga in tako začne bitko. Storil je, kot mu je bilo zapovedano, in je dal z zvrnjeno črko X, zaokroženo pri vrhu, narisati na ščite Kristusov znak.75 S tem znamenjem oborožena vojska je zgrabila za meče. Sovražnik je prišel naproti brez cesarja in je prečkal most, vojski sta se spopadli v enako široki bojni vrsti, oboji so se borili z največjo močjo, $d a$, ne eni ne drugi ne znajo bežati ... ${ }^{6}$ (7) V mestu [Rimu] je izbruhnil upor, vojskovodjo [Maksencija] so obtožili, da je opustil skrb za blaginjo države - na svoj rojstni dan ${ }^{77}$ je namreč priredil cirkuške igre - ko je nenadoma ljudstvo v en glas vzkliknilo, da Konstantina ni mogoče premagati. (8) Prestrašen zaradi tega vzklika se je umaknil in ukazal pogledati v sibilinske knjige, v katerih so odkrili, da bo na ta dan umrl sovražnik Rimljanov. (9) Ob tem odgovoru je prepričan v zmago stopil naprej in se podal v bitko. Za njegovim hrbtom se je most zrušil. Zatem se je bitka zaostrila, nad bojno vrsto je bila božja roka. Maksencijevi

Iz Afrike, od koder je prišlo kakih 20.000 vojakov. Maksencij je imel sicer za obrambo Rima na voljo okrog 40.000 vojakov (Kuhoff, Diokletian, 897).

75 Avtor opisuje stavrogram ( $\mathbf{(})$, ki je bil prvotno ligatura grških črk tau $(\mathrm{T})$ in rho (P). Po Evzebijevi okrog 339 napisani biografiji (1.28 in nasl.) je Konstantin videl križ čez sonce z napisom »s tem boš zmagal« ( v naslednjih sanjah ukazal uporabiti kot zaščitni znak. Kot kaže, je Konstantin to pozneje prikazal sam, videnja so pogost topos pri opisih dobrih cesarjev. Ko je Konstantin pred spopadom dal na ščite narisati zmagovalni znak, je bitka postala neke vrste spopad bogov, v kateri se je Kristus prvič izkazal kot pomočnik v bitki (gl. Demandt, Spätantike, 83).

76 Vergilij, Eneida 10.757, prevod Fran Bradač. Mišljen je »rojstni dan« Maksencija kot cesarja, dan nastopa njegove vladavine. 
vojaki so se prestrašili, obrnil se je $\mathrm{v}$ beg in pohitel do porušenega mostu, množica bežečih ga je stisnila in potisnila v Tibero. ${ }^{78}$ (10) Ko se je ta resnično srdita bitka končala, je bil z velikim veseljem senata in rimskega ljudstva Konstantin sprejet kot cesar; izvedel je za Maksiminovo nezvestobo, saj je zasegel njegova pisma, našel je kipe in slike. (11) Senat je Konstantinu v zahvalo za njegovo vrlino dodelil najvišji naslov, ki ga je zase zahteval Maksimin. Ko je ta izvedel za novico o osvoboditvi mesta, jo je sprejel tako, kot bi bil premagan sam. (12) Ko je izvedel za senatovo odločitev, se je od bolečine tako razvnel, da je odkrito priznal sovraštvo in je najvišjega cesarja obsipal z žalitvami in zasmehovanjem.

[45] (1) Ko je uredil zadeve v mestu, se je Konstantin zaradi bližajoče zime umaknil v Mediolan. Tja je prispel tudi Licinij, da bi sprejel svojo ženo. ${ }^{79}$ (2) Ko je Maksimin videl, da sta oba zaposlena s pripravo poročnih svečanosti, je sredi najhujše zime premaknil vojsko iz Sirije in jo izčrpano v dvojnem maršu privedel v Bitinijo. (3) Zaradi velikega deževja, sneženja, blata, mraza in naporov so pomrle vprežne živali vseh vrst, žalostni pogled na njihova trupla vzdolž ceste je vojakom napovedoval izid prihodnje vojne in podoben poraz. (4) Sam ni ostal le znotraj svojega ozemlja, pač pa je po prehodu čez ožino z vojsko prispel pred vrata Bizanca. Tam je bila vojaška posadka, ki jo je za tak primer namestil Licinij. To je poskušal Maksimin najprej pridobiti z darovi in obljubami, nato pa prestrašiti s silo in obleganjem, vendar niso pomagale ne sila ne obljube. (5) Potem ko je minilo že enajst dni, kar bi lahko poslali sle in pisma cesarju [Liciniju], so se vojaki predali, ne zaradi nezvestobe, ampak zaradi majhnega števila. Od tod je šel naprej do Herakleje, kjer je bil zadržan na enak način in je izgubil nekaj dni. (6) Licinij je v naglici z maloštevilno vojsko prispel do Adrianopla; ${ }^{80}$ ko je oni [Maksimin] sprejel predajo Perinta in se je tam nekoliko zadržal, je šel naprej do postaje na osemnajsti milji; naprej ni mogel, ker je Licinij že zasedel naslednjo postajo, oddaljeno prav toliko milj. (7) Ta [Licinij] je v okolici zbral vse vojake, kolikor jih je mogel, in se odpravil proti Maksiminu, a bolj zato, da bi ga zadržal, kot da bi začel bitko ali upal na zmago. Maksimin je namreč poveljeval vojski

78 Konstantinova zmaga v bitki pri Milvijskem mostu je imela daljnosežne posledice (gl. Demandt, Spätantike, 82-85). Prinesla je prevlado krščanstva, ki bi se sicer gotovo vsaj zamaknila. Senat je po zmagi Konstantinu posvetil slavolok s prizori iz te bitke, v Maksencijevi baziliki pa so postavili velik Konstantinov kip. Konstantin je na veliko podpiral tudi gradnjo cerkva.

79 Konstantinovo polsestro Konstancijo.

80 Dan. Edirne v evropskem delu Turčije blizu meje z Grčijo in Bolgarijo. 
sedemdeset tisoč oboroženih, sam pa jih je zbral komaj trideset tisoč. (8) Njegovi vojaki so bili razpršeni na vse strani in jih zaradi stiske s časom ni bilo mogoče zbrati.

[46] (1) Ko sta se vojski približali ena drugi, se je zdelo, da se bo bitka kmalu začela. (2) Tedaj je dal Maksimin Jupitru zaobljubo, da bo v primeru zmage iztrebil in popolnoma uničil ime kristjanov. (3) Naslednjo noč je k spečemu Liciniju pristopil Gospodov angel in ga opomnil, naj takoj vstane in s celotno vojsko moli k najvišjemu Bogu; če to stori, bo zmaga njegova. (4) Potem je sanjal, da je po teh besedah vstal in da je isti angel, ki ga je opomnil, stal poleg njega in ga učil, kako in s katerimi besedami naj moli. (5) Tedaj se je prebudil iz spanca in ukazal poklicati pisarja ter mu narekoval besede, kot jih je slišal: (6) »Najvišji Bog, prosimo te, sveti Bog, prosimo te. Vso pravičnost izročamo tebi, svoje rešenje izročamo tebi, svojo oblast izročamo tebi. Po tebi živimo, po tebi smo zmagovalci in srečni. Najvišji, sveti Bog, usliši naše prošnje; k tebi stegujemo svoje roke, usliši nas, sveti, najvišji Bog.« (7) To so zapisali v več primerkih in razdelili vsem poveljnikom in tribunom, da podučijo svoje vojake. Vsem je zrasel pogum, verjeli so, da jim je bila z neba sporočena zmaga. (8) Cesar je kot dan za bitko določil majske kalende, ko se je dopolnila osma obletnica njegovega [Maksiminovega] imenovanja; na ta način bo premagan na dan svojega prihoda na oblast, tako kot je bil oni [Maksencij] premagan $\mathrm{v}$ Rimu. (9) Maksimin je želel priti bolj zgodaj; dan prej je zjutraj razporedil bojno vrsto, da bi naslednji dan praznoval obletnico kot zmagovalec. V tabor je bilo sporočeno, da se je Maksimin že premaknil. Vojaki so zgrabili za orožje in krenili naproti. Vmes je bila nerodovitna in gola ravnina, ki jo imenujejo Ergen.$^{81}(10)$ Obe bojni vrsti sta videli druga drugo. Licinijanci so odložili ščite, sneli čelade, stegnili roke proti nebu, sledili zgledu poveljnikov in za cesarjem izgovarjali molitev. Vojska, ki jo je čakala poguba, je zaslišala mrmranje tistih, ki so molili. (11) Ti so trikrat ponovili molitev, si polni poguma nadeli čelade na glave in dvignili ščite. Cesarja sta stopila naprej na pogovor. (12) Maksimin se ni dal pregovoriti $\mathrm{k}$ miru, preziral je Licinija in je mislil, da ga bodo vojaki zapustili, ker je bil pri darovih zadržan, sam pa bolj razsipen. Vojno je namreč začel, ker je mislil, da bo Licinijevo vojsko pridobil brez spopada in da bo potem $\mathrm{z}$ dvojnimi silami krenil nad Konstantina.

[47] (1) Pomaknili so se bliže, zapele so trobente, prapori so se pomaknili naprej. Licinijanci so začeli boj in napadli sovražnike. Ti od strahu niso mogli niti izvleči mečev niti metati kopij. (2) Maksimin je jezdil pred bojno vrsto in poskušal licinijance zavesti zdaj s proš- 
njami, zdaj z darovi. Toda nikjer ni bil uslišan. Bil je celo napaden in je pobegnil nazaj k svojim. Njegova bojna vrsta je bila razbita brez odpora, tolikšno število legij, tolikšno vojaško moč so potolkli maloštevilni. (3) Nihče se ni spomnil na svoj ugled, nihče na svoj pogum, nihče na stara odlikovanja - kot bi bili žrtvovani smrti, ne kot da bi prišli v bitko, tako jih je najvišji Bog izročil sovražniku, da jih je pobil. Nenadoma je izgubila življenje velika množica. (4) Maksimin je uvidel, da se je vse odvilo drugače, kot je pričakoval. Odvrgel je škrlat, zgrabil suženjsko obleko, pobegnil in prešel morsko ožino. Polovica njegove vojske je padla, druga se je predala ali obrnila v beg; sram pred begom je namreč odpravil pobegli cesar. (5) Ta [Maksimin] pa je na majske kalende, to je čez eno noč in en dan $\langle\ldots\rangle$, prispel v Nikomedijo na drugo noč, čeprav je kraj bitke oddaljen sto šestdeset milj; zgrabil je ženo in otroke ter skupaj z nekaterimi spremljevalci iz palače pohitel proti Vzhodu. (6) Toda v Kapadokiji se je ustavil, potem ko so se okrog njega zbrali vojaki, ki so pobegnili z Vzhoda. Tako je spet oblekel cesarsko oblačilo.

[48] (1) Licinij je sprejel del [Maksiminove] vojske, jo prerazporedil med svoje in prepeljal vojsko v Bitinijo nekaj dni po bitki. Prišel je $\mathrm{v}$ Nikomedijo in se zahvalil Bogu, s pomočjo katerega je zmagal in na junijske ide [13. junija], v letu, ko sta bila on in Konstantin tretjič konzula [313], napisal namestniku naslednje pismo o obnovi Cerkve ter mu ukazal, naj ga javno objavi. ${ }^{82}$

(2) »Potem ko sva se midva, jaz, cesar Konstantin, in jaz, cesar Licinij, srečno sestala $v$ Mediolanu in obravnavala vse, kar zadeva javno korist in varnost, sva med drugimi stvarmi, za katere sva menila, da bodo koristile številnim ljudem, sklenila, da morava najprej izdati odredbe, ki bodo vsebovale čaščenje božanstev, da bi kristjanom in vsem drugim omogočila svobodno sledenje veri, kot bo kdo želel, tako da bodo vsa božanska bitja, ki sedijo na nebeškem prestolu, nam in vsem ostalim, ki so pod najino oblastjo, prijateljska in milostna. (3) Zato sva štela za koristno in pravilno, da je treba sprejeti takšno odločitev, po kateri ta možnost ne bo odvzeta nikomur, najsi se predaja krščanskim nazorom ali tisti veri, ki jo ima za najprimernejšo, tako da nam bo najvišje božanstvo, ki ga častimo po svobodni volji, lahko v vsem ponujalo običajno naklonjenost in dobrohotnost.

(4) Zato naj tvoja vdanost ve, da se nama je zdelo primerno preklicati vse pogoje, ki so v prejšnjih razglasih prihajali v tvoj urad, in da je treba odstraniti vse tisto, kar se je zdelo povsem narobe in tuje najini milosti, tako da lahko zdaj vsak posameznik svobodno in nemoteno 
sledi krščanski veri brez kakega strahu, da bo pri tem oviran. (5) Menila sva, da morava tvoji skrbi te stvari predstaviti zelo izčrpno, da boš uvidel, kako sva tem istim kristjanom dopustila popolno in svobodno izpoved svoje vere. (6) Ker jasno vidiš, da sva jim to odobrila, lahko tvoja vdanost razume, da sva podobno odprto in neomejeno čaščenje svoje vere dopustila tudi ostalim zavoljo miru v našem času, tako da ima vsak neomejeno svobodo v čaščenju tistega, kar izbere. To sva naredila zato, da se ne bi zdelo, kako podcenjujeva katerikoli nauk ali vero. (7) Razen tega sva oba, kar zadeva krščansko skupnost, določila tudi naslednje. Če se izkaže, da je kdo v preteklem obdobju iz sredstev naše ali kakšne druge zakladnice kupil prostor, v katerem so se imeli kristjani navado zbirati - v zvezi s čimer so v tvojo skrb prihajali dopisi v skladu s prej določenimi predpisi - potem se morajo ta ista mesta vrniti kristjanom brez kakršnegakoli plačila ali odškodninskega zahtevka in brez kakršnegakoli dvoumja. (8) Če pa je kdo takšna mesta dobil v dar, jih mora prav tako čimprej vrniti istim kristjanom. Tako tisti, ki so jih kupili, kot tudi tisti, katerim so bila podarjena, se morajo, če želijo zaupati najini dobrohotnosti, obrniti na najinega namestnika, da bo najina milost poskrbela tudi zanje. Vse to je treba s tvojim posredovanjem prenesti krščanski skupnosti brez kakršnegakoli odloga. (9) Ker je znano, da so imeli kristjani v lasti ne le kraje, kjer so se običajno zbirali, temveč tudi drugo, kar je zakonito pripadalo njihovi skupnosti - torej cerkvam, ne posameznemu človeku - boš vse to brez kakršnegakoli dvoumja ali razprave po prej navedenih odredbah ukazal vrniti tem istim kristjanom, to je njihovi skupnosti in občini; vsak, ki to vrne brez odškodnine, lahko pričakuje odškodnino od najine dobrohotnosti. (10) V vseh teh stvareh boš moral dati omenjeni krščanski skupnosti svojo podporo, da se bodo najine odredbe čimprej čimbolj dobrovoljno izpolnile, da bo najini modrosti tudi s tem zagotovljen javni mir. (11) Kot sva že omenila zgoraj, bo na ta način božja naklonjenost do naju, ki sva jo izkusila v tako važnih stvareh, za vse čase ugodno ostala ob najinih podvigih za splošno srečo. (12) Da bi te najine odredbe $\mathrm{z}$ najino dobrovoljnostjo lahko prišle do vseh, boš ta javni razglas obesil kot svoj lastni razglas in ga objavil tako, da izvajanje najine dobrohotnosti nikomur ne bo ostalo neznano."

(13) Po objavi tega pisma je Licinij tudi ustno ukazal, da se morajo zbirališča povrniti v prejšnje stanje. Tako je od uničenja Cerkve do njene obnove preteklo deset let in štirje meseci.

[49] (1) Ko je Licinij zasledoval tirana $z$ vojsko, se je ta [Maksimin] umaknil in pohitel $\mathrm{k}$ soteskam gorovja Taver. Tam je $\mathrm{z}$ gradnjo obzidja in stolpov skušal zapreti pot, a ker je bil od tam pregnan, ker so zmagovalci prodirali povsod, je slednjič pobegnil v Tarz. (2) Ko je bil tam 
obkoljen po kopnem in po morju in ni imel več upanja na izhod, se je zaradi tesnobe in strahu zatekel k smrti kot zdravilu za nadlogo, ki mu jo je Bog nakopal na glavo. (3) Toda pred tem se je natlačil s hrano in nalil z vinom, kot to počnejo tisti, ki mislijo, da to delajo zadnjič, in spil strup. Vendar je napolnjenost želodca zmanjšala njegovo moč, tako da ni mogel takoj delovati, temveč je sprožil le neke vrste mlahavost, podobno kugi. Tako se je njegovo življenje v trpljenju podaljšalo. Takrat je začel v njem besneti strup. (4) Zaradi njegove moči se mu je vnela notranjost, neznosne bolečine so ga privedle do blodenj, tako da je bil štiri dni obseden $\mathrm{z}$ brezumjem, $\mathrm{z}$ rokami je kopal po zemlji in jo jedel, kot bi bil lačen. (5) Potem je po dolgih in strašnih mukah z glavo tolkel ob zid, tako da so mu oči stopile iz jamic; ko je končno izgubil vid, je videl Boga, kako mu sodi ob služabnikih v belih oblačilih. (6) Glasno je zakričal kot tisti, ki jih mučijo, da tega ni storil on, ampak drugi. Zatem je, kot bi bil v svojih mukah v to prisiljen, začel priznavati Kristusa in takoj zatem moliti in prositi, naj se ga usmili. (7) Tako je sredi muk, kot bi ga živega žgali, izročil svojega grešnega duha in umrl na grozljiv način.

[50] (1) Tako je Bog premagal vse preganjalce svojega imena, da od njih ni ostalo niti deblo niti kakršnakoli korenina. (2) Kajti takoj, ko je Licinij prišel na oblast, je najprej izdal ukaz, naj ubijejo Valerijo, česar se Maksimin v svojem besu ni drznil niti po svojem begu, ko je že gledal lastno smrt, in enako tudi Kandidijana, ki ga je rodila konkubina in posvojila Valerija, ker sama ni mogla imeti otrok. (3) Ta ženska se je, potem ko je izvedela za Licinijevo zmago, preoblekla in pomešala med njegove spremljevalce, da bi videla, kaj se bo zgodilo s Kandidijanom. Ker se je pojavil v Nikomediji in ker se je zdelo, da uživa naklonjenost, je bil ubit, ne da bi prej karkoli slutil. (4) Ob novici o njegovi smrti je ona [Valerija] takoj pobegnila. Tudi Severovega sina Severijana, ki je Maksimina spremljal na begu, je dal [Licinij] prav tako obsoditi na smrt in ubiti pod obtožbo, da je nameraval po njegovi [Maksiminovi] smrti obleči škrlat. (5) Vsi ti so se že dolgo bali Licinijevega zla in so raje bivali pri Maksiminu, z izjemo Valerije, ki je zahtevo, naj odstopi od svojih nasledstvenih pravic na vse Maksimijanove [Galerijeve] dobrine, zavrnila tako Liciniju kot Maksiminu. (6) Tudi Maksimu, najstarejšemu Maksiminovemu sinu, ki je imel takrat osem let, in njegovi sedemletni hčerki, ki je bila zaročena s Kandidijanom, je on [Licinij] vzel življenje. Najprej pa je dal njuno mater vreči v Oront, kjer je sama pogostokrat ukazala v valovih utopiti častne ženske. (7) Tako so vsi neverni po resnični in pravični božji sodbi prejeli to, kar so počeli drugim. 
[51] (1) Valerijo, ki je petnajst mesecev potovala po različnih provincah, so končno prepoznali pri Tesaloniki, zajeli so jo skupaj z materjo in kaznovali. (2) Obe ženski so kaznovali pred veliko množico, ki je sočustvovala z njima zaradi tolikšnega padca. Bili sta obglavljeni, njuni telesi pa so vrgli v morje. Tako sta jima bila čednost in stan v pogubo.

[52] (1) Menil sem, da moram vse to verodostojno popisati - govorim namreč nekomu, ki je s tem seznanjen - tako kot se je zgodilo, da ne bi izginil spomin na tako velike stvari in da bi, če bi kdo želel napisati zgodovino, ne izkrivil resnice in ne bi zamolčal grehov teh ljudi do Boga ali božje sodbe proti njim. (2) Njegovi večni milosti se moramo zahvaliti, da se je končno ozrl na zemljo in sklenil svojo čredo, ki so jo opustošili grabežljivi volkovi in je bila delno tudi razgnana, obnoviti ter zbrati in iztrebiti divje zveri, ki so božji čredi uničile pašnike in raztrgale ograde. (3) Kje so tista velika in med pogani slavna imena Jupitrovcev in Herkulijcev, ki sta si jih najprej nerazumno prisvojila Diokles in Maksimijan, pozneje pa so jih prevzeli in obdržali njuni nasledniki? Gospod jih je uničil in postrgal z obličja zemlje. (4) Slavimo torej z navdušenjem zmagoslavje Boga, proslavljajmo Gospodovo zmago $s$ hvalnicami, slavimo $\mathrm{z}$ dnevnimi in nočnimi molitvami, slavimo, da bi mir, ki ga je po desetih letih dal svojemu ljudstvu, potrdil na veke. Ti pa, najdražji Donat, ki si si zaslužil, da te Bog usliši, prosi Boga, naj bo svojim služabnikom blago in usmiljeno naklonjen, naj vse hudičeve zvijače in napade odvrne od svojega ljudstva in naj v cvetoči Cerkvi ohrani večni mir. 


\section{LITERATURA}

Brandt, Hartwin. „Galerio legislatore." V: Costantino prima e dopo Costantino / Constantine before and after Constantine, ur. Giorgio Bonamente, Noel Lenski in Rita Lizzi Testa, 17-24. Bari: Edipuglia, 2012.

Bratož, Rajko, Rimska zgodovina, prvi del: Od začetkov do nastopa cesarja Dioklecijana. Zbirka Zgodovinskega časopisa 33. Ljubljana: Zveza zgodovinskih društev Slovenije, 2007.

Bratož, Rajko. Med Italijo in Ilirikom: Slovenski prostor in njegovo sosedstvo v pozni antiki. Zbirka zgodovinskega časopisa 46. Ljubljana: Zveza zgodovinskih društev Slovenije, 2014.

Bratož, Rajko. »Forma e contenuto della toleranza religiosa dall'edito di Gallieno all'edito di Galerio.« V: Costantino prima e dopo Costantino / Constantine before and after Constantine, ur. Giorgio Bonamente, Noel Lenski in Rita Lizzi Testa, 25-46. Bari: Edipuglia, 2012.

Carlà-Uhink, Filippo. Diocletiano. Bologna: Società editrice il Mulino, 2019.

Corcoran, Simon. The Empire of the Tetrarchs: Imperial Pronouncements and Government AD 284-324. Oxford: Oxford University Press, 2. izd., 2000.

Cook, Patrick. »Lactantius on the Death of Galerius: A Re-Reading of De Mortibus Persecutorum 33."Vigiliae Christianae 73 (2019): 385-403.

Demandt, Alexander. Die Spätantike: Römische Geschichte von Diocletian bis Justinijan 284-565 n. Chr. Handbuch der Altertumswissenschaft 3.6. München: C. H. Beck, 2. izd., 2007.

Dillon, John Noël. »The Emperor's New Prose: The Style of the Legislation of Diocletian. "V: Diocleziano: La frontiera giuridica dell'impero, ur. Werner Eck in Salvatore Puliatti, 285-343. Pavia: Pavia University Press, 2018.

Donciu, Ramiro. L'empereur Maxence. Bari: Edipuglia, 2012.

Eck, Werner. »Die Neuorganisation der Provinzen und Italliens unter Diokletian. "V: Diocleziano: La frontiera giuridica dell'impero, ur. Werner Eck in Salvatore Puliatti, 111-151. Pavia: Pavia University Press, 2018.

Giacchero, Marta. Edictum Diocletiani et collegarum de pretiis rerum venalium. Genova: Istituto di storia antica e scienze ausiliarie, 1974.

Glas, Toni. Valerian: Kaisertum und Reformansätze in der Krisenphase des Römischen Reiches. Paderborn: Ferdinand Schöningh, 2014. 
Gordon, Octavian. Lactantius de mortibus persecutorum: Studiu filologic. Bukarešta: Editura Universtãții din București, 2009.

Kolb, Frank. »La Tetrarchia: Struttura, fondamento e ideologia del potere imperiale. "V: Diocleziano: La frontiera giuridica dell'impero, ur. Werner Eck in Salvatore Puliatti, 3-43. Pavia: Pavia University Press, 2018.

König, Ingemar. Origo Constantini: Anonymus Valesianus 1. Trier: Verlag Trierer Historische Forschungen, 1987.

Kuhoff, Wolfgang. Diokletian und die Epoche der Tetrarchie: Das römische Reich zwischen Krisenbewältigung und Neuaufbau (284-313 n. Chr.). Frankfurt na Majni: Lang, 2001.

Lauffer, Siegfried. Diokletians Preisedikt. Berlin: Walter de Gruyter \& Co., 1971.

Leadbetter, Bill. Galerius and the Will of Diocletian. Roman Imperial Biographies. London: Routledge, 2009.

Lenski, Noel. »The Significance of the Edict of Milan. « V: Constantine: Religious Faith and Imperial Policy, ur. A. Edward Siecienski, 27-56. London: Routledge, 2017.

Marcone, Arnaldo. »Editto di Galerio e fine delle persecuzioni.« V: Costantino prima e dopo Costantino / Constantine before and after Constantine, ur. Giorgio Bonamente, Noel Lenski in Rita Lizzi Testa, 47-57. Bari: Edipuglia, 2012.

Maver, Aleš. Religiosi et profani principes: Rimski cesarji od Avgusta do Teodozija v latinskem krščanskem zgodovinopisju 4. in 5. stoletja. Maribor: Zgodovinsko društvo dr. Franca Kovačiča, 2009.

Moreau, Jacques, izd. Lactance De la mort des persécuteurs. Sources Chrétiennes 39. Pariz: Cerf, 1954.

Porena, Pierfrancesco. »L'amministrazione palatina di Diocleziano e dei tetrarchi: Comitatus, consilium, consistorium. V: Diocleziano: La frontiera giuridica dell'impero, ur. Werner Eck in Salvatore Puliatti, 63-110. Pavia: Pavia University Press, 2018.

Puech, Vincent. Constantin: Le premier empereur chrétien. Pariz: Elipses, 2011.

Rémy, Bernard. Dioclétien: L'empire restauré. Pariz: Armand Colin, 2016. Rougé, Jean, in Daniel De Decker. De mortibus persecutorum: Un libelle au service de la propagande constantinienne. Bibliotheca patristica Iassiensis 4. Iaşi: Editura Universității Alexandru Ioan Cuza, 2013.

Søby Christensen, Arne. Lactantius the Historian. København: Museum Tusculanum Press, 1980.

Städele, Alfons, prev. Laktanz De mortibus persecutorum / Die Todesarten der Verfolger. Fontes Christiani 43. Turnhout: Brepols, 2003. 